\title{
Analysis of an Authentic Historical Italian Cosmetic Talc Sample - Further Evidence for the Lack of Cancer Risk
}

\author{
Edward B. Ilgren ${ }^{1}$, Carlo Sartorio ${ }^{2} \&$ John A. Hoskins ${ }^{3}$ \\ ${ }^{1}$ Visiting Professor of Neuropathology \& Expert Investigator in Environmental Neurotoxicology, University of \\ Tarapaca, Chile. Formerly, University of Oxford, Faculty of Biological \& Agricultural Sciences, Department of \\ Neuropathology, Oxford, UK \\ ${ }^{2}$ Retired Judge. Pinerolo, Italy \\ ${ }^{3}$ Independent Consultant, Haslemere. UK. Formerly, Medical Research Council, Leicester, UK \\ Correspondence: Edward B. Ilgren, Visiting Professor of Neuropathology \& Expert Investigator in \\ Environmental Neurotoxicology, University of Tarapaca (UTA), Arica 1000000, Chile. Tel: 56-58-2-215420-124. \\ E-mail: dredilgren@aol.com
}

Received: July 28, 2017

doi:10.5539/ep.v6n2p6
Accepted: August 22, 2017

Online Published: September 29, 2017

URL: https://doi.org/10.5539/ep.v6n2p6

\begin{abstract}
Italian talc from the Pinerolo Mines in North West Italy is known for its extreme purity. Several historical investigations of these mines have demonstrated very small amounts of tremolite in the host rock that occasionally found their way into the mined ore. However, more than sixty years of epidemiological studies of the Pinerolo miners and millers have failed to demonstrate any attendant cancer risk and show that this trace tremolite contamination is of no biological significance.

Claims made that the Pinerolo Italian cosmetic talc produced prior to 1975 were contaminated with asbestos, principally tremolite, have been difficult to refute given the lack of authentic historical samples of commercial products. We now describe the analytical findings of a recently discovered authentic historical sample.

Sample analyses of this material showed only a few non-asbestiform tremolite fibres - a finding discussed in the light of the historical (pre-1975) studies of this talc deposit: no serpentine (chrysotile) or amphibole fibres were detected.

The numerical concentration of tremolite fibres in the talc sample was $3.687 \times 10^{6}$ fibres/gram, corresponding to a mass concentration of 0.722 parts per million.
\end{abstract}

Keywords: asbestos contamination, cosmetic talc, Fontane mine, Pinerolo, tremolite

\section{Introduction}

Italian talc from the Pinerolo Mines in North West Italy is known for its extreme purity. More than sixty years of epidemiological studies of the Pinerolo miners and millers have failed to demonstrate any attendant cancer risk (Pira et al. 2017; Pira, personal communication (June 2017)). This finding is clearly supportive of its purity and lack of asbestos contamination. The purity stems from the nature of geological formation of the talc body, its attendant mineralogical characteristics, and the historical steps used to beneficiate and purify the ore during its mining and milling.

Historical investigations of the Pinerolo mine have demonstrated very small amounts of tremolite in the host rock around the talc ore body. Trace amounts may find their way into the ore but the lack of any biological activity supported by the epidemiological studies of the Pinerolo miners and millers demonstrates, amongst other factors discussed herein, how insignificant any tremolite contamination must be.

It has been claimed that Pinerolo Italian cosmetic talcs produced prior to 1975 were contaminated with asbestos. Such claims have been difficult to refute given the lack of authenticable historical samples of commercial products formulated with Pinerolo cosmetic talc. This situation has now changed after the finding of one such historical sample described in this report. This material was analysed by TEM. The discovery and findings from the analysis of the sample are the subject of this paper. 


\section{Material and Methods}

\subsection{Finding the Historical Cosmetic Talc Sample}

A bottle of Mannetti \& Roberts cosmetic talc, date stamped 1971, was discovered by the second author (CS) in his family home in Pinerolo, Italy. This author is the grandson of the founder of the Society of Val Chisone (SVC) Pinerolo mine founded in 1907 as well as the son of the SVC mining manager (Sr. Pier Sartorio) and is a retired Senior Judge based in Pinerolo who also wrote his thesis on the economic profile and history of Pinerolo talc (Sartorio, 1978). A section of one of his historical family homes had been sealed off for over fifty years following the death of several family members. It was opened in October 2015 to prepare the premises for sale. A bottle of Robert's M\&R borotalc was found in a closet in the sealed part of the family home. The bottle was half full at the time of discovery. Photographs of the plastic bottle are shown in the A figures: figures A1 to A7.

The first author (EI) was in Torino at the time the family home was opened in 2015 to discuss the current status of the epidemiological update of the Pinerolo miner and miller study with Professor Pira and his colleagues. EI knew CS well from his earlier visits to Torino to study Pinerolo talc. When CS told EI he had found a bottle of historical Pinerolo cosmetic talc, EI in turn asked Dr Eric Chatfield if he would be willing to analyze the sample. Dr. Chatfield, formerly Chairman of the International Organization for Standardization (ISO) fiber committee, agreed to do so and EI sent the bottle directly to Dr. Chatfield's office in Toronto by courier post. with the request that the sample be examined by transmission electron microscopy (TEM) for the presence of serpentine and amphibole fibres.

\subsection{Specimen Preparation (Chatfield, 2000)}

A sub-sample of approximately 0.1 gram of the talc was dispersed in $100 \mathrm{~mL}$ of $0.1 \mu \mathrm{m}$ filtered, distilled water in a $200 \mathrm{~mL}$ glass beaker. The beaker was placed in an ultrasonic bath for a period of 5 minutes in order to disperse the sub-sample.

Polycarbonate filters of $25 \mathrm{~mm}$ diameter and $0.2 \mu \mathrm{m}$ pore size were selected for the analytical filters for the analysis. Prior to use, all polycarbonate analytical filters were treated for a period of 15 minutes in a mixture of $50 \%$ concentrated hydrofluoric acid and 50\% concentrated hydrochloric acid to ensure that no silicate minerals were present on the filters prior to use (AP1). Analytical filters were prepared using the filtration techniques of ISO 13794:1999 (AP2), in order to ensure uniform deposition of particulate on the filters. The active area of the filters was $199 \mathrm{~mm}^{2}$.

Initially, a laboratory funnel blank filter was prepared by filtration of $40 \mathrm{~mL}$ of the distilled water used in the analysis. Aliquots of $0.03 \mathrm{~mL}, 0.1 \mathrm{~mL}, 0.3 \mathrm{~mL}$ and $1.0 \mathrm{~mL}$ of the talc suspension were filtered to provide a range of particulate loadings, one of which would be suitable for TEM examination

TEM specimens were prepared from the polycarbonate filters using the techniques in ISO 13794:1999 (AP2).

\subsection{TEM Examination}

During examination of the TEM specimens, a fibre was defined as a particle with parallel or stepped sides and a length to width (aspect) ratio equal to or greater than 3 to 1 . The TEM specimens were examined at a magnification of 21,500. Fibres were identified on the basis of selected area electron diffraction (SAED) combined with energy dispersive X-ray analysis (EDXA). In order to determine the concentration of serpentine and amphibole fibres in the talc sample, 100 grid openings of the TEM specimens prepared from the selected sample filter were examined. One hundred grid openings of the TEM specimens prepared from the laboratory funnel blank were also examined.

\section{Results}

Specimens for TEM were prepared from a filtered $0.1 \mathrm{~mL}$ aliquot of a suspension of the talc and found to have an appropriate particle loading for TEM analysis which was then carried out. Subsequent analysis was made of 100 grid openings of the specimens prepared from this aliquot. A summary of the results of the analysis is shown in Table 1.

Examples of TEM micrographs, EDXA spectra and SAED patterns of the sample are shown in the B figures: Figs B1-B12. In the EDXA spectra in Figs B6, B10, B12, the X-ray peaks from copper, chromium and zinc display system peaks from the copper support grid and the specimen holder.

During a preliminary examination of the TEM specimens, a fibre suspected to be tremolite was detected on Grid Opening A-G3-2. This fibre was approximately $4.9 \mu \mathrm{m}$ long and $0.27 \mu \mathrm{m}$ wide, and is shown in figure B5. Figure B6 shows the EDXA spectrum obtained from this fibre, and the spectrum corresponds to tremolite. Figure B7 shows a zone-axis SAED pattern and figure B8 the corresponding calibration pattern from a thin film gold 
standard. The zone-axis pattern is consistent with the 010 zone-axis of tremolite. However, this fibre could not be included in the quantitative results, because it was not found during a systematic TEM examination and also because it occurred on a grid opening partially obscured by the grid address, which meant that the grid opening area could not be measured.

The TEM micrograph in figure B1 shows a number of platy talc particles. Figure B2 shows platy talc particles and an elongated fragment of talc. Figures B3 and B4 show talc fibres.

Two other tremolite fibres were detected (Table 2). Figures B9 and B11 show their TEM micrographs and figures B10 and B12 the corresponding EDXA spectra. The weight percent tremolite was calculated according to the procedure in ISO 22262-2:2014 (A3).

No serpentine (chrysotile) or other amphibole fibres were detected during the TEM examination of the specimens.

The numerical concentration of tremolite fibres in the talc sample was $3.687 \times 10^{6}$ fibres/gram. The mass concentration of tremolite fibres in the talc sample was 0.0000722 weight percent $(0.722$ parts per million).

\section{Discussion}

We believe this is the first analysis in recent years of an authenticable historical sample of Pinerolo cosmetic talc. The methods for specimen preparation, examination, and analysis were conducted using state of the art analytical procedures as described above (AP1, AP2, AP3).

\subsection{Claims of Asbestos Contamination in Early Talc Samples}

The findings of this report and others such as AERE UK (1972) and Mc Crone et al. (1972) dispel earlier claims (Lewin, Salom \& Kraus, 1972) that Pinerolo cosmetic talc could be contaminated by asbestos. Paoletti, Caiazza, Donelli \& Pocchiari (1984) reported "tremolite asbestos" in two of five Italian cosmetic talc samples but neither was identified as coming from the Fontane mine. IARC (2010) as well as Hildrick-Smith (1976) and Price (2010) seriously questioned all the claims of historical (pre-1976) contamination (Cralley, Key, Groth, Lainhart \& Ligo, 1968; Rohl \& Langer 1974; Rohl, Langer \& Selikoff. 1976; Longo \& Young, 1979). Baan et al. (2006) said the "available information is sparse and poorly reported and the analyses were often inadequate to identify the fibers derived". Crane (2000) also remarked that "historically in the literature you will find that there are references to this kind of material where non-asbestos tremolite has been called asbestos or asbestiform improperly".

\subsection{Purity Studies of Fontane Mine Talc}

\subsubsection{Studies of Talc Ore}

Parmeggiani (1948) emphasized the great purity of the talc from Val Germanasco. Grill, Pagliani \& Sacchi (1955) extensively studied the talc mines of Val Germanasco for more than 50 years and described a large sampling survey in the Fontane mine conducted in the summer of 1953. They also demonstrated the clear distinction between the zones of talc and amphibole in geological diagrams of the Fontane mine both in horizontal and vertical views. The four samples (given to Grill and his colleagues by Sr Piero Sartorio, Technical Director of SVC and the father of the second author) taken from pure talc ore and analyzed using optical petromicroscopy and petrochemical analysis contained no tremolite. Lightfoot, Kingston \& Pooley (1972) conducted a sampling survey of the Fontane mine in a manner similar to Grill et al. (1955). Sr Piero Sartorio probably helped obtain the samples for these analyses as well. Sixteen samples "could be classified as material likely to be processed as ore". These were analyzed using optical microscopy, Differential Thermal Analysis (DTA) and Thermogravimetric analysis (TGA), TEM, and X-ray diffraction (XRD). Of the 16 samples, tremolite was found in two (designated: I5, "General Ore"; 141, "Face 2") but only using optical microcopy, not by TEM or XRD. Wagner, Berry, Hill, Skidmore, \& Pooley, (1979) and Rubino, Scansetti, Piolatto, \& Romano (1976) also reviewed the work of Lightfoot et al. (1972) and concluded there was no evidence of asbestos in the talc from the Fontane mine.

\subsubsection{Studies of Milled Talc and Final Product Samples}

In February, 1972, Ing. Pier Sartorio, the Director of the Technical Committee of the Societa Talco e Grafite Val Chisone based in Pinerolo (Torino) (and father of the second author of this paper), commissioned Prof. Ing. Enea Ocella of the Mining Institute of the Torino Polytechnic Institute to determine petrographically the amount of tremolite in two samples from consignments of SVC Extra ('5Theta') talc taken from the two operating mills, the one at San Sebastiano and the other at Malannoggio at different times (Certificate No. 71/7211) (SVC Report (1972)). The precise amounts used for analysis were simply termed "small". These were dispersed in eugenol for microscopic study using phase contrast, dark field, bright field and polarized light microscopy. "The only 
particles that occasionally occur were those that showed the optical features of tremolite. Their proportion range in number between 1 and 2 per 10,000 parts" giving a weight percent less than $0.02 \%$. The calcium concentration was found to be "close to the lowest limit of sensitivity of the spectroscope $(0.01 \%)$ ". An undated statement by SVC, though probably written close in time to the aforementioned report, was issued by SVC entitled the "The use of talcs of Pinerolo in the pharmaceutic-cosmetic sector" (Pinerolo Talc (undated)). The statement said "The talc of Pinerolo, for cosmetic use, that's mined from the deposits of the Chisone and Germanasca Valleys in the North-Western Alps, has to be considered as a product of very high quality because the amounts of "hard and soft" silicates and impurities is practically negligible and because its structure is not fibrous or needle shaped. The talc "is included between the characteristic rocks of this part of the Alps (gneiss, mica-schists and dolomitic limestone)" but the talc is "very far from every horizon of serpentine and asbestos rocks that could invalidate its purity".

Pooley and Rowlands (1975) examined three samples of cosmetic talc (Extra A, '5Theta', and Extra Superior) from the Fontane mine using X-ray powder diffractometry (XRD powder), electron microscopy with electron diffraction (EM-EDAX), and quantitative differential thermal analysis with X-ray diffraction (DTA - XRD) and failed to find tremolite in any sample. They also analyzed six other historical batches of '5Theta' talc by XRD dating back to 1949 and again failed to find tremolite in any of them. The Colorado School of Mines (CSM) reported the findings of analyses of two lots of milled Fontane mine talc (available from the author). The first (CSM 24 June 1971) report found a total of 3 non-talc needles which were found to be free of tremolite when studied by XRD (CSM 2 Sept 1971). A third (CSM 7 Sept 1972) study of Fontane talc final product also indicated the lack of amphibole or serpentine. The Polytechnic Institute of Torino analyzed two samples of '5Theta' Fontane mine talc, each pulverized in different mills (the one at Malannaggio and the other at San Sebastien). No asbestos was found using phase contrast or bright field polarizing light microscopy. Wagner et al. (1977) said "Extensive investigation of this particular grade of talc ('5Theta') had been performed for the two year period prior to the start of the animal experimentation, and samples which were over 30 years old had been examined as well as more recent imports. Virtually no change in the mineralogical composition of the material has been detected. No asbestos minerals of either the tremolite or chrysotile varieties have been detected in the many samples examined." Verdel and Sperduto (1983) failed to find tremolite in Fontane mine talc by XRD or infra red spectroscopy. The UK Atomic Energy Research Establishment (AERE) (1972) studied two samples of '5Theta' talc using optical microscopy, SEM and TEM and failed to find tremolite. Hamilton, Fox, Buckley, Henderson \& Griffiths, (1984) examined '5Theta' talc by TEM and failed to find asbestos. Ferret and Morreau (1991) analyzed five Italian talcs using XRD and TGA. None contained tremolite. Clerici, Gecchele, Patrucco \& Longo (1988) analyzed Fontaine mine Extra Sup talc and said it was free of asbestos using XRD analysis. Zazenski et al. (1995) and Zazenski (1998) said "The quality of the talc found in Val Germanasca is recognized worldwide for its brightness and purity. It is considered to be the finest talc in the world, and has recently obtained ISO 9002, ISO 9002 (1992), BS 7750 (1995), ISO 14001 (1996), ISO 9001:2000 (2003), 2004 GMP (2004) quality certifications."

To celebrate 100 years of mining the famed "Bianco de le Alpi" (the White of the Alps), the Ecomuseo Regionale delle Miniere e della Val Germanasca (Regional Ecomuseum of Mines and the Germanasca Valley) and the "Rio Tinto Minerals - Luzenac Val Chisone" Company, in collaboration with the Piedmont Region and the Comunità Montana Valli Chisone e Germanasca, organised an exhibition entitled "TALC...the valleys, stories and people" (See: 100 YEARS (2007)) which emphasized the purity of the talc.

\subsection{Early Studies of Fontane Mine Air Samples and Air Samples taken from Aerosols Generated from the End Product}

Parmeggiani (1948) studied the chemical characteristics of the dust in the 'Pinerolose' talc mines and tremolite was not recorded. Gecchele, Gola \& Patrucco (1984) analyzed air samples from the Fontane mine and said tremolite was not identified in any of the fibrous elements (aspect ratios $>3: 1$, longer than $5 \mu \mathrm{m}$ ).

Wagner et al. $(1977,1979)$ generated very high dust concentrations $\left(10.8 \mathrm{mg} / \mathrm{m}^{3}\right)$ of ' 5 Theta' talc for use in their rat inhalation studies. Skidmore, in the Discussion of Wagner et al. (1977) said the talc cloud contained up to 1300 particles $/ \mathrm{ml}$ longer than $1 \mu \mathrm{m}$ of which 1 to $2 \%$ were longer than $20 \mu \mathrm{m}$ with diameters between 1 and 2 $\mu \mathrm{m}$. Pooley said in the Discussion of the same paper, that XRD, DTA, TEM with EDAX of the 'many fibrous particles analyzed' (aspect ratios $>3: 1$ ) "were laths of talc or chlorite".

\subsection{Relevance of the Three Tremolite Fibers Found in This Study}

The finding of the three tremolite fibers in the cosmetic talc bottle sample is of no biological consequence for the following reasons: 
1) One of the three fibers cannot be included in the quantitative results since it was not found upon systematic TEM examination and was also partially obscured by the grid address. Moreover, given the high level of sensitivity of the analysis, the finding of one fiber is not statistically different from the background lab counts so there is an equal chance that the one fiber came from some other source aside from the talc sample under study. The same applies to the two fibers found within the systematic TEM examination.

2) All three fibers were less than $5 \mu \mathrm{m}$ long and are therefore of no biological consequence on the basis of short length (e.g. Ilgren, 2008).

3) None of the fibers fulfil the definition of the asbestiform habit provided by EPA/600/R-93/116 i.e. their aspect ratios are all less than 20:1. Regarding the two fibers in the systematic TEM examination, B-C3-6 has highly irregular stepped sides and is clearly not, morphologically, asbestiform. C-C3-4 has rough sides and end terminals. The $0.25 \mu \mathrm{m}$ width of A-G3-2 is also suggestive of its non-asbestiform nature.

4) The total fiber concentration of $3.687 \times 10^{6}$ fibers per gram appears very high but this is totally offset by their ultra-low weight percentage calculated to be 0.72 parts per million. Consequently, the fiber concentrations, as measured by phase-contrast optical microscopy (PCOM), even if generated by hyper-aerosolization, would be exceedingly low. Addison, Davies, Robertson \& Willey (1988) studied the release of asbestos fibers from different soils treated in specific media by addition of known percentages of asbestos using "hyper-aerosolization" methods. A sample of sand was spiked with different kinds of asbestos of which amosite appeared to produce the greatest fiber concentration. If one assumed that the three fibers found in the talc sample were all longer than $5 \mu \mathrm{m}$, one can ask: what airborne tremolite fibre concentration could result if the talc sample was very liberally applied in a closed bathroom or "hyper-aerosolized" from domestic use? Even though Addison et al. (1988) had as a target total dust concentrations of $5 \mathrm{mg} / \mathrm{m}^{3}$ these would correspond to snow storm conditions. A sand sample spiked with $0.001 \%$ of amosite would only produce an upper concentration of 0.14 $\mathrm{f} / \mathrm{ml}$. If the sample contained 0.72 parts per million or ca $0.0000001 \%$, the resulting tremolite fiber concentrations would almost certainly be immeasurable (or no different than background). But again, these determinations are quite theoretical since none of the fibers were longer than $5 \mu \mathrm{m}$ nor were any asbestiform and thus, on each basis, of no biological importance (Ilgren, 2004a, b). Jones, Apsley, Clark, Addison \& Van Orden (2010) also conducted tests similar to those done by Addison et al. (1988) in collaboration with the Institute of Occupational Medicine (Edinburgh) and derived similar results. Therefore, whilst Addison (1994) said "it would be necessary to take action to control for the asbestos emissions if soils containing higher levels than $0.001 \%$ were to be handled without significant health risks", the quantitative and qualitative considerations referable to this study clearly indicate Pinerolo cosmetic talc can be handled and used without any significant health risk.

\subsection{Mineralogical Basis for the Origin of the Tremolite Fibers}

The Roberts talc sample analyzed in this report was derived from the Fontane talc mine located in the Piedmont region of Northwest Italy in Valle Germanasco ca. $50 \mathrm{~km}$ Northwest of Turin. The largest town in the immediate vicinity of the mine is Pinerolo. The main road going to Val Germanasco leaves Pinerolo and splits after $20 \mathrm{kms}$ to form Val Chisone. Whilst the talc mines of this area are commonly called, collectively, the 'Pinerolese' mines of Val Chisone and Val Germanasco. However, the studies described herein concern Val Germanasco, not Val Chisone since the Fontane mine from whence the cosmetic talc was mined was from the former not the latter. Frequently, reference has been made erroneously to Val Chisone as a source of the Fontane mine talc but the confusion has probably been engendered by the name of the company "Societa Talco e Grafite Val Chisone".

Historically, the Fontane mine was the largest of at least six talc mining sites which ran the length of Val Germansco from ca. 2000 meters elevation at Prali to ca. 600 meters elevation at Pomaretto. These were developed over at least one hundred years (Genre, 2010; 100 YEARS, (2007)). Over time these were associated with a host of smaller holdings that resulted in an extreme contiguity of sites (100 YEARS, (2007)). However, by 1966, economic constraints had caused most of the mines to be amalgamated into three sections. The largest was Giana on the left side of the Germansca River and by 1988, the entire Fontane mine was worked from Giana and to a lesser extent from Crossetto on the right. Most of the sampling done to date was from these two parts of the Fontane mine, particularly the former, Giana.

The Fontane talc mine ore body consisted a series of lenses ('en eschalon') with a typical 'rosary' shape. It could be considered as a very vast but extremely irregular seam of talc that narrowed and widened from a few centimetres to 6 to 8 meters (Del Greco and Pelizza, 1984). Peila, Oggeri, Oreste, Polizza \& Monticelli (2008) has described the geological environment of the Germanasca Valley and its structural history as an ophiolitic oceanic complex, better known as the "Calcescisti (or Piemontese) nappe". The continental domain, known as the "Dora Maira massif", extends for an important part of the length of the Germanasca Valley along a tectonic 
contact zone. Most of the existing and exhausted talc mines are distributed along this tectonic contact.

The mode of formation of the talc found in the Fontane mine in Val Germanasco has been geologically classified based according to the nature of the host rock (Ferret and Moreau, 1991) and the conditions (of temperature, pressure, duration and nature of hydrothermal solutions) under which that was formed. These indicate that the Pinerolo talc arises from the 'metamorphism' of siliceous dolomites and carbonates (dolomite, magnesite) (Ferret and Moreau, 1991; Peila et al, 2008). These directly influence the mineralogy and in turn the quality and purity of the talc (Addison and Langer, 2000; Ferret and Moreau, 1991), producing what is widely known to the finest grade and highest purity talc known and thus suitable for use in the cosmetic, pharmaceutical and food industries (Pooley and Rowlands, 1975; Ferret and Moreau, 1991).

Macroscopically, the talc seam in the Fontane mine is highly homogeneous (Dean to Goudie, 1972). Tremolite does not form within the ore itself, only in the host rock as the specific conditions of temperature, pressure and chemistry required for tremolite formation are not met during the formation of the talc itself (Ilgren, 2004a), only in the host rock. Indeed, for tremolite to form in the asbestiform habit as 'tremolite asbestos', the conditions must be much more exacting indeed (Ilgren, 2004b). The prerequisites for the formation of asbestiform tremolite are apparently never met either in the talc ore or the host rock in the Pinerolo talc mines on the basis of the studies produced to date.

The host-rock walls of the Pinerolo talc mines are composed of quartz - muscovite schists and gneissose rocks (Pooley and Rowlands, 1975; also see Del Greco, Patrucco \& Pelizza (1989) and Peila et al, (2008). These contain various minerals which can be 'inherited from the parent rock' or formed together with it (also see e.g. Zazenski et al, (1995); Ferret and Moreau, (1991). These minerals may include very minor amounts of tremolite within the occasionally included rocks such as carbonates. Whilst some carbonate inclusions may be large, they are discrete from the talc seam itself (Pooley and Rowlands, 1975) and thus readily identifiable at source (see below) making them easy to remove.

\subsection{Tremolite in Rockwall Fontane Mine Samples}

Grill et al. (1955) took 23 samples from rock walls of three different galleries of the Fontane mine. Nineteen (19) were through bedrock. Of the 19, ten (10) contained amphibole, largely in minor amounts. All were characterized as acicular, prismatic 'minute needles or crystals'. Lightfoot et al. (1972) took 30 samples of host rock and analyzed these using different methods including optical microscopy, differential thermal analysis (DTA), thermal gravimetric analysis (TGA), transmission electron microscopy (TEM), and x-ray diffraction (XRD). Seven (7) of the 30 were said to contain some form of amphibole using optical microscopy.

XRD did not confirm amphibole in four of the samples identified optically. These four samples were the following (as numbered by Lightfoot et al. (1972) as:

\section{I7 ('Mica Schist')}

12 ('Footwall sample? Amphibolite / amphibole footwall')

31 ('Black inclusion, Face 1') and;

35 ('Massive carbonate from rear end of working')

TEM and XRD examination indicated the fibers found in another one of the seven samples (19 - 'Tremolite / quartz / talc') optically identified as amphibole were tremolite. However, these examinations also said the tremolite was 'coarse bladed'. Moreover, the figure legend of sample 19 said very few fibers were produced when it was crushed and those that were fibrous in nature were 'thick and stubby with less than $50 \%$ of the particles elongated in shape'. This clearly indicated they were not asbestiform.

In another of the seven samples that were optically identified as amphibole (I20 - 'Amphibole sample Giana level 1212'), tremolite was found by XRD and the legend to the TEM photo of the sample referred to 'compact particles with numerous lath forms'. However, the appearance of the materials produced upon crushing was similar to those described above for sample I9, again indicating they were not asbestiform.

Finally, in the remaining sample optically identified as amphibole (4 - 'Face 10 sample with obvious amphibole'), XRD confirmed the presence of tremolite but no morphological details were given.

Therefore, none of the samples optically identified as amphibole by Lightfoot et al. (1972) could be confirmed to be tremolite asbestos.

Further comments by Lightfoot et al. (1972) confirm the non-asbestiform nature of the samples. They stated:

'No fibrous material whatsoever was found when carbonate material only was comminuted. The morphology of 
particles produced from the footwall rocks i.e. limestone, marble, gneiss and the amphibolites were also very compact'

'Selected area diffraction patterns which were obtained from the lath like particles in no way resembled the typical amphibole fibre diffraction pattern. They were generally very distorted patterns containing streaks rather than spots indicating a rather stressed and deformed material.'

'Diffraction patterns from these particles matched those obtained from the platy particles with which they were associated and in no way resembled the typical amphibole diffraction pattern obtained from single amphibole asbestos fibres.'

'To assess the particles produced from the pure amphibole mineral tremolite, found in three of the specimens, small crystals of the mineral were taken from the hand specimens and crushed separately. An examination of the finer particles produced revealed stubby electron dense fibres associated with irregular lumps of the same mineral. Diffraction patterns from these fibres were similar to those obtained from the commercial amphibole minerals, although they were more difficult to obtain because of the greater thickness of these particles.'

Taken together, these findings fully support the notion that the tremolite fibers found in the sample analyzed by Lightfoot et al. (1972) were not asbestiform and therefore similar in nature to the few tremolite fibres found in the Fontane mine in earlier studies by others and consequently of no biological consequence.

\subsection{Alternative Sources of Tremolite and Non-tremolite Amphibole Exposure Contamination}

There could be sources of amphibole asbestos, including tremolite, crocidolite and amosite, in the Fontane mine totally unrelated to the talc ore body. These could come from mines or quarries with different commercial needs. SVC thus had smaller holdings that included non-talc mining activities, primarily aimed at the extraction of copper and graphite (www.valchisone.it/web/minatori.asp) some of which may have been associated with the Fontane talc operations and/or its workers.

Commercial amphibole asbestos may also have been used in the Fontane mine for infrastructural support particularly before its peak operations. During the period (1949 - 1966) Fontane mine talc was being exploited by several major cosmetic talc producers and the operations were owned and run by the SVC founded in Pinerolo in 1907 by Dr. Carlo Sartorio's grandfather (also see Genre, (2010)). Indeed, between 1950 and 1960 , the SVC Fontane talc mine saw perhaps the maximum number of miners in the valley (Martelli, 2010 pers. comm.). Examination of the trend of SVC's total talc production from 1947 to 1983 (Del Greco and Pelizza, 1984) showed that nearly all of the talc came exclusively from the Fontane mine. With the expansion of SVC's activities came the opening of new mines within the Fontane mine itself. These included though were not limited to the mines of Giana (1935), Paola (1937), Vittoria, (1941), S Pietro (1947) and Carla (1955). In concert with the development of these new mines, extensive support systems were put in place. Historically, these included internal and external road and transport systems, hydroelectric plants, and diverse machinery (100 YEARS, 2007) which may have required the use of commercial amphibole asbestos. These support systems were described in more detail for the main mine of the Fontane talc production area (Giana) by Del Greco et al. (1989) particularly for the production of compressed air plants, electric power supply systems, internal transport including general loading and haulage, and ventilation. Again, many of these could have introduced amphibole from sources totally unrelated to the talc ore body. The Fontane talc miners and millers could therefore have been exposed to such materials and so have been at risk of developing asbestos related disease from sources totally unrelated to the talc per se.

\subsection{Methods of Purification used at the Fontane Talc Mine and Mill}

Various methods were used to purify or "beneficiate" Fontane mine talc during its mining and milling. Starting with the ore at source, many 'contaminating' inclusions were discrete and visibly distinct from the ore itself. Because of this, they could largely be eliminated by selective mining, selective grinding, classification, flotation, and magnetic separation techniques amongst other methodologies (Ferret and Morreau, 1991) to yield a very pure product. The main methods used specifically at the Fontane talc mine to eliminate such impurities have been described in detail by various sources (e.g. Del Greco and Pelizza, 1984; Clerici et al., 1988; Del Greco, Pelizza, Sartorio \& Stragiotti, 1976). These methods eliminated most of the major impurities from the talc ore at source.

From 1949 to 1966, talc exploitation was probably achieved by a back-fill method that filled rising horizontal strips with loose fill (Del Greco and Pelizza, 1984; Clerici et al., 1988). The talc mineral bodies were split up into panels 40 meters long along a vertical line, the width of the panel down the slope being ca. $80-100 \mathrm{~m}$. The panel was then divided into two strips, each $20 \mathrm{~m}$ long, and every strip was exhausted into slices. Much of this 
work was done by hand including the selection and removal of most potential tremolite containing inclusions (vs). This historical hand selection method resulted in a higher quality, though lower volume of talc than from ore mined after 1974 when more mechanized methods were introduced (Del Greco and Pelizza, 1984; also see e.g. Zazenski et al., 1995 for a more general discussion of hand selection and beneficiation methods). Thus, prior to 1974 , the talc was mined in very narrow stopes which followed 'good' ore layers. At this time, only the 'good' ore was extracted generally using hand-held drills. In this way, the 'poor' ore could readily be left in place. After 1974, the adoption of more mechanical methods allowed larger stopes to be exploited but this increased the possibility that more inclusions could be left in the talc ore at source (Patrucco, 2012 pers. comm.)

Historically, ore and waste rock were removed from the Fontane mine through a talc loading and haulage system largely centered at the Giana level (Del Greco et al., (1989); also see Cian, Gecchele, \& Patrucco (1984)). From here, production was hauled to the mine entry portal to which the talc mined at the other levels was also transferred via a shaft equipped with a hoisting plant. This can be seen in the 'indicative planimetric' diagrams of the Fontane mine shown by Del Greco and Pelizza (1984) and in the horizontal and vertical projections of the Fontane mine itself shown by Del Greco et al. (1976). Giana was closed in 1995 and Crosseta in 2002. The purity of the talc ore was also increased using additional post-milling/pre-milling beneficiation methods (Patrucco, 2012 pers. comm.) as well as through the entire milling process itself which is too detailed for discussion here.

\subsection{Epidemiological Support for Purity}

The failure to find any attendant cancer risk in the Pinerolo miners and millers after nearly 70 years of epidemiological study, attests to the purity of the talc and the inconsequential nature of a few tremolite fragments found in the end product. (Parmeggiani, 1948; Scansetti, Rasetti \& Ghemi (1963), Rubino, Maranzana, Pettinati, \& Scansetti, (1963), Rubino et al. (1976), Rubino, Scansetti, Piolatto, \& Gay (1979); Coggiola et al., (2003), Pira et al., 2017; Pira, pers comm. (2017); also see additional commentary supportive of the lack of attendant cancer risk by Wild (2006), Baan et al. (2006) and IARC (2010).

The failure to find asbestos related disease in the Fontane miners and millers is not surprising making it even much less of a surprise that it does not exist in cosmetic talc end users. The amount of tremolite fragments to which the miners and millers may have been exposed would naturally be exponentially greater than to anyone ever using Pinerolo Italian cosmetic talc. Indeed, if the Fontane talc per se or any tremolitic contaminant was able to produce asbestos disease, it would certainly have been revealed by the epidemiological studies of the Pinerolo talc miners and millers after nearly 70 years of epidemiological study. The failure to find any attendant cancer risk in the Pinerolo miners and millers after this period of epidemiological study not only attests to the purity of the talc but also to the wholly innocuous nature of whatever tremolite fragments may be released during the excavation, mining and milling process. This also applies to current claims of an attendant ovarian cancer risk to cosmetic talc. Thus, the wives and children of the Pinerolo miners and millers were domestically and environmentally exposed historically to large amounts of talc as were the many women who packaged the talc at different factories in several parts of Italy, particularly Alessandria and Florence. Further very significant exposure was also incurred by Italian residents particularly the aristocracy in the late $19^{\text {th }}$ and $20^{\text {th }}$ centuries. Such residents included many non-Italian residents as well. If cosmetic talc was a cause of ovarian cancer, it would certainly have been manifest in major ovarian cancer clusters in all of these populations particularly those end users who, historically, very liberally used cosmetic talc.

Therefore, despite the long term historical use of Fontane talc, the fact that the diagnosis of ovarian cancer has been historically secure for more than 130 years (Vargas, 2014) and because many populations, particularly the aristocracy with access to the best medical facilities, one would have expected to find a soaring increase in the incidence of ovarian cancer for more than a century. The failure to observe such an enormous increase particularly in relation to the end use of cosmetic talc for the last 130 years, attests to its purity and safety.

\section{Conclusions}

The findings of this study are therefore totally in concert with and supportive of the lack of any cancer risk of Pinerolo Italian cosmetic talc. A conclusion which is clearly related to its purity.

\section{Acknowledgements}

The authors would like to thank Dr Eric Chatfield for his analysis of the talc sample.

\section{References}

100 YEARS: FROM “TALCO E GRAFITE” TO "RIO TINTO - LUZENAC VAL CHISONE". (2007). (available from the principal author) 
Addison, J. (1994). Report (dated: February 1994): Vermiculite is not Asbestos, pp.30. (Available from the author of this paper)

Addison, J., \& Langer, A. M. (2000). Draft comments on the NTP draft report on carcinogens background document for talc asbestiform and non-asbestiform. op. cit. Finley, B. L., Benson S. M., Marsh G. M. (2017) Cosmetic talc as a risk factor for pleural mesothelioma: a weight of evidence evaluation of the epidemiology. Inhalation Toxicology, 29(4), 179-185.

Addison, J., Davies, L. S. T., Robertson, A., \& Willey, R. J. (1988). The release of dispersed asbestos fibres from soils. IOM Edinburgh, Research Report TM/88/14.

AERE UK. (1972, 26 $6^{\text {th }}$ April). Mott, B.W., Interim Report for Johnson and Johnson Ltd. On Italian 00000 grade talc and chemical characterization. Journal of Toxicology and Environmental Health, 2, 255-284.

Baan, R., Straif, K., Grosse, Y., Secretan, B., El Ghissassi, F., \& Cogliano, V. (2006) Carcinogenicity of carbon black, titanium dioxide and talc. Lancet Oncology 7:295-296. https://doi.org/10.1016/S1470-2045(06)70651-9

Chatfield, E. J. (2000). A Rapid Procedure for Preparation of Transmission Electron Microscopy Specimens from Polycarbonate Filters. In M. E. Beard \& H. L. Rook (Eds.), Advances in Environmental Measurement Methods for Asbestos, ASTM STP 1342 (pp. 242-249). American Society for Testing and Materials, West Conshohocken, PA.

Cian, P., Gecchele, G., \& Patrucco, M. (1984). Studio teorico sperimentale sulla ventilazioni nella miniera di talco di Fontane. (Theoretical and experimental study on ventilation in the Fontane talc mine). Bollettino della Associazione Mineraria Subalpina, XXI, 3, Torino.

Clerici, C., Gecchele, G., Patrucco, M., \& Longo, G. (1988). Auxiliary Ventilation Plant and Air Dispersed Particulates: An Experimental Study in the Stopes of an Italian Talc Mine. In Sampling and Control of Mineral Dusts. pp. 1011-1018.

Coggiola, M., Bosio, D., Pira, E., Piolatto. P. G., La Vecchia, C., Negri, E., ... Bacaloni, A. (2003). An update of a mortality study of talc miners and millers in Italy. American Journal of Industrial Medicine, 44, 63-9. https://doi.org/10.1002/ajim.10240

Cralley, J., Key, M., Groth, D. H., Lainhart, W. S., \& Ligo, R. M. (1968) Fibrous and Mineral Content of Cosmetic Talcum Products. American Industrial Hygiene Association Journal, 29(4), 350-354. https://doi.org/10.1080/00028896809343015

Crane, D. T. (2000). Background information regarding the analysis of industrial talcs. June 12, 2000 Report. U.S. Department of Labor, Occupational Safety and Health Administration, Salt Lake Technical Center, Salt Lake City, UT.

CSM June 24 1971: Report on Particle size and shape distributions of Grantham, Italian and Vermont talc.

CSM September 2 1971: Letter to W.H. Ashton (Johnson and Johnson) from M.G. Pattengill giving point count analyses of talc samples.

CSM September 7 1972: Letter to R. Rolle (Johnson and Johnson) from W.T. Caneer giving XRD results.

Dean Letter. (1972). (available from author).

Del Greco, O., \& Pelizza, S. (1984). The underground Fontane talc mine: main characteristic of the deposit and exploitation methods. Bollettina della Associazione Mineraria Subalpina, 21(1-2), 85-92.

Del Greco, O., Patrucco, \& Pelizza, S. (1989). La miniera in sotteraneo di talco di Fontane: caratteristiche del glacimento, metodi di coltivazione, impiantistica. (The underground Fontane talc mine: a general review of deposit characteristics, mining method, underground installations and fittings). Bollettina della Associazione Mineraria Subalpina, 26(2-3), 415-430.

Del Greco, O., Pelizza, S., Sartorio, P., \& Stragiotti, L. (1976). Coltivazione con ripiena cementata nella miniera di talco di Fontane (Growing (mining?) with the Fontane TALC mine in cemented backfill??) Bollettina della Associazione Mineraria Subalpina, 13(3), 262-272.

Ferret, J., \& Morreau, P. (1991). Mineralogy of talc deposits NATO ASI SE VOL G21, pp. 625-638.

Gecchele, G., Gola, G., \& Patrucco, M. (1984). Le norme della Polizia Mineraria nell'attività di cava. In QUARRY AND CONSTRUCTION n. XII, pp. 23-25.

Genre, R. (2010). la Miniera. Quaderno di documentazione 4, Communita Montana Valli Chisoni e Germanasco. 
Grill, E., Pagliani, G., \& Sacchi, L. (1955). La Genesi Talco della valle della Germanasca (Alpi Cozie) (Genesis of Talc in the Germanasca valley (Cottian alps). pp. 442-490.

Hamilton, T. C., Fox, H., Buckley, C. H., Henderson, W. J., \& Griffiths, K. (1984). Effects of talc on the rat ovary. British Journal of Experimental Pathology, 65,101-106.

Hildick-Smith, G. Y. (1976). The Biology of Talc. British Journal of Industrial Medicine, 33(4), 217-229. https://doi.org/10.1136/oem.33.4.217

IARC Monographs on the Evaluation of Carcinogenic Risks to Humans. Volume 93 (2010) Carbon Black, Titanium Dioxide, and Talc. Vol. 93: Carbon Black, Titanium Dioxide and Non-Asbestiform Talc (Report of meeting 7-14 February 2006). pp. 305-309.

Ilgren, E. B. (2004a). The Biology of Cleavage Fragments: A Brief Synthesis and Analysis of Current Knowledge. Indoor \& Built Environment, 13, 343-356. https://doi.org/10.1177/1420326X04047563

Ilgren, E. B. (2004b). Coalinga Chrysotile: A Short Fibre, Amphibole Free, Chrysotile: Part V - Lack of Amphibole Asbestos Contamination. Indoor \& Built Environment, 13, 325-341. https://doi.org/10.1177/1420326X04047657

Ilgren, E. B. (2008). The Fiber Length of Coalinga Chrysotile: Enhanced Clearance due to Its Short Nature in Aqueous Solution with a Brief Critique on "Short Fiber Toxicity". Indoor \& Built Environment, 17, $20-41$. https://doi.org/10.1177/1420326X07086427

International Organisation for Standardization. (1999). ISO 13794:1999. Ambient air - Determination of asbestos fibres - Indirect-transfer transmission electron microscopy method.

International Organisation for Standardization. (2014). ISO 22262:2014. Air quality - Bulk materials - Part 2: Quantitative determination of asbestos by gravimetric and microscopical methods.

Jones, A. D., Apsley, A., Clark, S., Addison, J., \& Van Orden, D. R. (2010). Laboratory tests to compare airborne respirable fibre mass and concentrations from soil samples from Libby, Montana. Indoor \& Built Environment, 19(2), 286-297.

Lewin, S. Z., Salom, I., \& Kraus, B. (1972). X-Ray diffraction analysis for asbestos in talc. Report from Dept. of Chemistry, New York University.

Lightfoot, J., Kingston, G. A., \& Pooley, F. D. (1972). Report of investigation of Italian mine samples and related powders. Dept. Mineral Exploitation, University College, Cardiff.

Longo, D. L., \& Young, R. C. (1979). Cosmetic talc and ovarian cancer. Lancet. 2(8138), 349-51. https://doi.org/10.1016/S0140-6736(79)90357-X

Mc Crone et al. (1972). Preliminary notes on the examination of shower-to-shower products for Johnson and Johnson. Study by Walter C. Mc Crone associates Inc.

Paoletti, L., Caiazza, S., Donelli, G., \& Pocchiari, F. (1984). Evaluation by electron microscopy techniques of asbestos contamination in industrial, cosmetic, and pharmaceutical talcs. Regulatory Toxicology and Pharmacology, 4, 222-235. https://doi.org/10.1016/0273-2300(84)90022-9

Parmeggiani, L. (1948). Le Pneumoconiosi dei minatori e dei mugnai di talco nel pinerolese.(Pneumoconiosis in talc miners and millers in the Pinerolo) Rassegna di medicina industriale e di igiene del Lavoro, 17, 16-48.

Peila, D., Oggeri, C., Oreste, P., Polizza1, S., \& Monticelli, F. (2008). Rodoretto talc mine (To, Italy): studies for the optimization of the cemented backfilling. RMZ - Materials and Geoenvironment, 55(2), 225-235.

Pinerolo Talc. (n.d.). The use of talcs of Pinerolo in pharmaceutic-cosmetic sector. (Available from the author).

Pira, E., Coggiola, M., Romano, C., La Vecchia, C., Pelucchi, C., Boffetta, P., \& Ciocan, C. (2017). Mortality of talc miners and millers from Val Chisone, Northern Italy: an updated cohort study. Journal of Occupational \& Environmental Medicine, 59, 659-664. https://doi.org/10.1097/JOM.0000000000000992

Pooley, F. D., \& Rowlands, N. (1975). Chemical and Physical Properties of British talc powders. Inhaled Particles, Pt 2, pp.639-46.

Price, B. (2010). Industrial-grade talc exposure and the risk of mesothelioma. Critical Reviews in Toxicology, 40(6), 513-530. https://doi.org/10.3109/10408441003646781

Rohl, A. N., \& Langer, A. M. (1974). Identification and Quantitation of Asbestos in Talc. Environmental Health Perspectives, 9, 95-109. https://doi.org/10.1289/ehp.74995 
Rohl, A. N., Langer, A. M., \& Selikoff, I. J. (1976). Consumer talcums and powders: mineral and chemical characterization. Journal of Toxicology and Environmental Health, 2, 255-284. https://doi.org/10.1080/15287397609529432

Rubino, G. F., Maranzana, P., Pettinati, L., \& Scansetti, G. (1963). Aspetti etio-patologici e clinici della pneumoconiosi da talco. (Pathological and clinical aspects of pneumoconiosis from talc) La Medicina di lavoro, 54, 496-506.

Rubino, G. F., Scansetti, G., Piolatto, G., \& Gay, G. (1979). Mortality and morbidity among talc miners and millers in Italy. In Lemen, R., \& Dement, J. M. (Eds.), Dusts and Disease (pp. 357-363). Pathotox, Illinois.

Rubino, G. F., Scansetti, G., Piolatto, G., \& Romano, C. A. (1976). Mortality Study of Talc Miners and Millers. Journal of Occupational Medicine, 18, 186-193. https://doi.org/10.1097/00043764-197603000-00013

Sartorio, C. (1978). Aspetti Technici ed Economici Della Produzione di Talco in Italia. (Technical and economic aspects of Talc production in Italy. ), Faculta di Economia e Commercio. Univ. de Torino. (154pp). (Unpublished thesis).

Scansetti, G., Rasetti, L., \& Ghemi, F. (1963). Clinical and radiological evolution of pneumoconiosis in the talc extracting industry. La Medicina di Lavoro, 54,746-749.

SVC Report. (1972). Petrographic Identification of Asbestos Silicates in Val Chisone (SVC) Talc. Torino. (Available from the author).

Vargas, A. N. (2014). Natural history of ovarian cancer. Ecancermedicalscience, 8, 465. Retrieved from https://www.ncbi.nlm.nih.gov/pmc/articles/PMC4176445/

Verdel, U., \& Sperduto, B. (1983). Composizione mineralogica dei principali talchi estratti nei Paesi mediterranei determinata mediante XRD e IRS.( Mineral composition of the major talc extracts in Mediterranean countries determined by XRD and IRS) Atti 12e Giornate Mediterranee Med. Lavoro, S. Margherita L., Genova: 35-36.

Wagner, J. C., Berry, G., Cooke, T. J., Hill, R. J., Pooley, F. D., \& Skidmore, J. W. (1977). Animal experiments with talc. In Walton, W. H., McGovern, B. (Eds.), Inhaled particles IV (Part 2, pp. 647-654). Oxford, UK, Pergamon Press.

Wagner, J. C., Berry, G., Hill, R. J., Skidmore, J. W., \& Pooley, F. D. (1979). An animal model for inhalation exposure to talc. In Dusts and disease - Occupational and Environmental Exposures to Selected Fibrous and Particulate Dusts. Pathtox publishers. pp. 389-392.

Wild, P. (2006). Lung cancer risk and talc not containing asbestiform fibres: a review of the epidemiological evidence. Occupational \& Environmental Medicine, 63, 4-9. https://doi.org/10.1136/oem.2005.020750

Zazenski, R. J. (1998). The commercial significance of talc. Comments inToxicology, 6, 313-326.

Zazenski, R., Ashton, W. H., Briggs, D., Chudkowski, M., Kelse, J. W., MacEachern, L., ... Gettings, S. D. (1995). Talc: Occurrence, characterization and consumer applications. Regulatory Toxicology \& Pharmacology, 21, 218-229. https://doi.org/10.1006/rtph.1995.1032 


\section{Appendixes}

Table 1. Talc analysis

Table 1. Results of Analysis of Talc Sample

\begin{tabular}{|c|c|c|c|c|c|c|c|c|c|}
\hline Sample & $\begin{array}{c}\text { Initial } \\
\text { Weight } \\
\text { of } \\
\text { Sub-Sample } \\
\text { (g) }\end{array}$ & $\begin{array}{c}\text { Dispersal } \\
\text { Volume } \\
(\mathrm{mL})\end{array}$ & $\begin{array}{c}\text { Volume } \\
\text { Filtered } \\
(\mathrm{mL})\end{array}$ & $\begin{array}{c}\text { Area } \\
\text { of } \\
\text { Analytical } \\
\text { Filter } \\
\left(\mathrm{mm}^{2}\right)\end{array}$ & $\begin{array}{l}\text { Mean } \\
\text { Grid } \\
\text { Opening } \\
\text { Area } \\
\left(\mathrm{mm}^{2}\right)\end{array}$ & $\begin{array}{c}\text { Number } \\
\text { of } \\
\text { Grid } \\
\text { Openings } \\
\text { Examined }\end{array}$ & $\begin{array}{l}\text { Number } \\
\text { of } \\
\text { Tremolite } \\
\text { Fibres } \\
\text { Detected }\end{array}$ & $\begin{array}{c}\text { Numerical } \\
\text { Concentration } \\
\text { of } \\
\text { Tremolite } \\
\text { Fibres } \\
\text { In } \\
\text { Original } \\
\text { Sample } \\
\text { (Fibres/gram) }\end{array}$ & $\begin{array}{c}\text { Weight } \\
\text { Percent } \\
\text { Tremolite } \\
\text { Fibres } \\
\text { In } \\
\text { Original } \\
\text { Sample }\end{array}$ \\
\hline $\begin{array}{l}\text { ROBERT'S BOROTALCO TALC } \\
100 \mathrm{~g} \text { Bottle Dated 3:71 } \\
\text { GTIN } 8001 \text { 8735 } \\
\text { Received 2015-11-23 }\end{array}$ & 0.1045 & 100 & 0.1 & 199 & 0.01033 & 100 & 2 & $3.687 \times 10^{6}$ & 0.0000722 \\
\hline
\end{tabular}


Figures A.

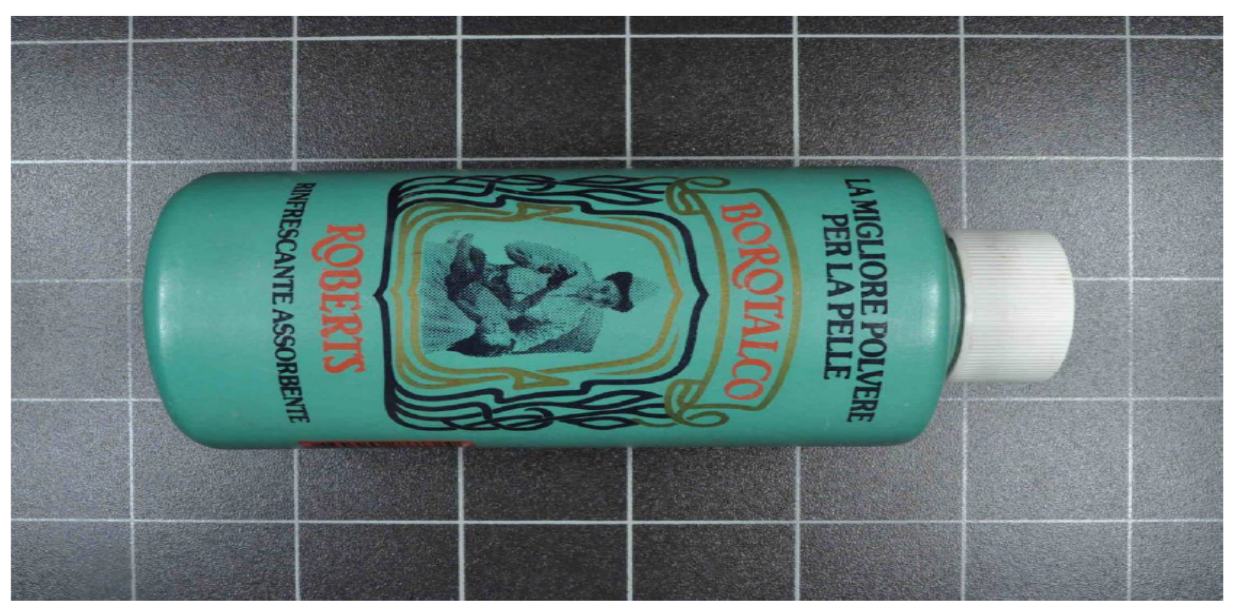

Figure A1. Front of Talc Bottle

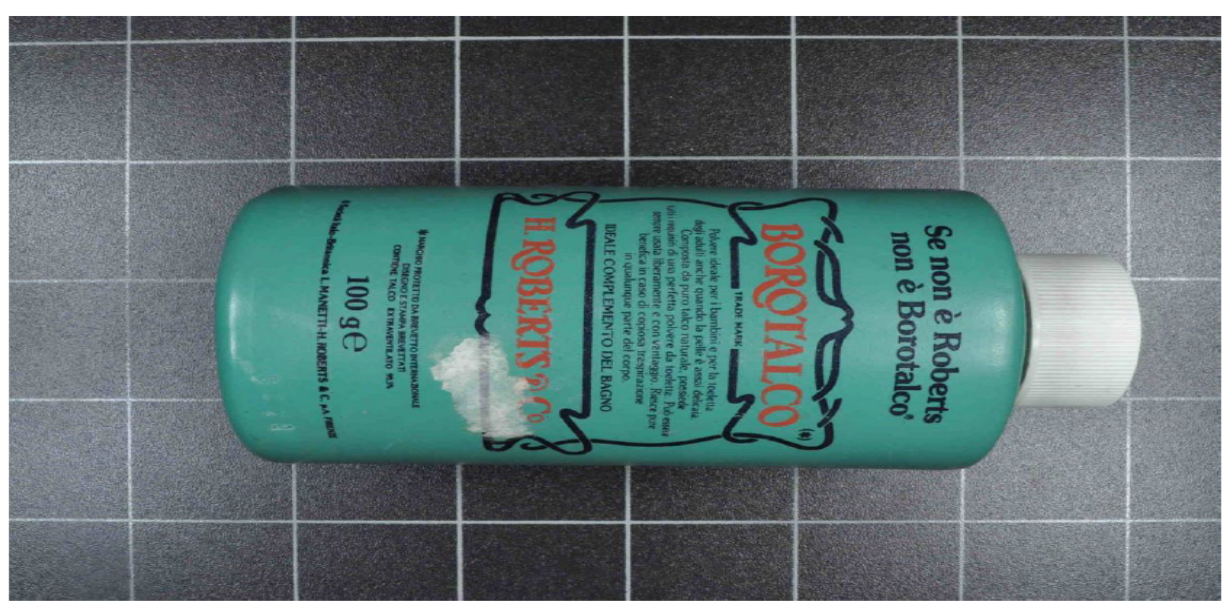

Figure A2. Back of Talc Bottle 


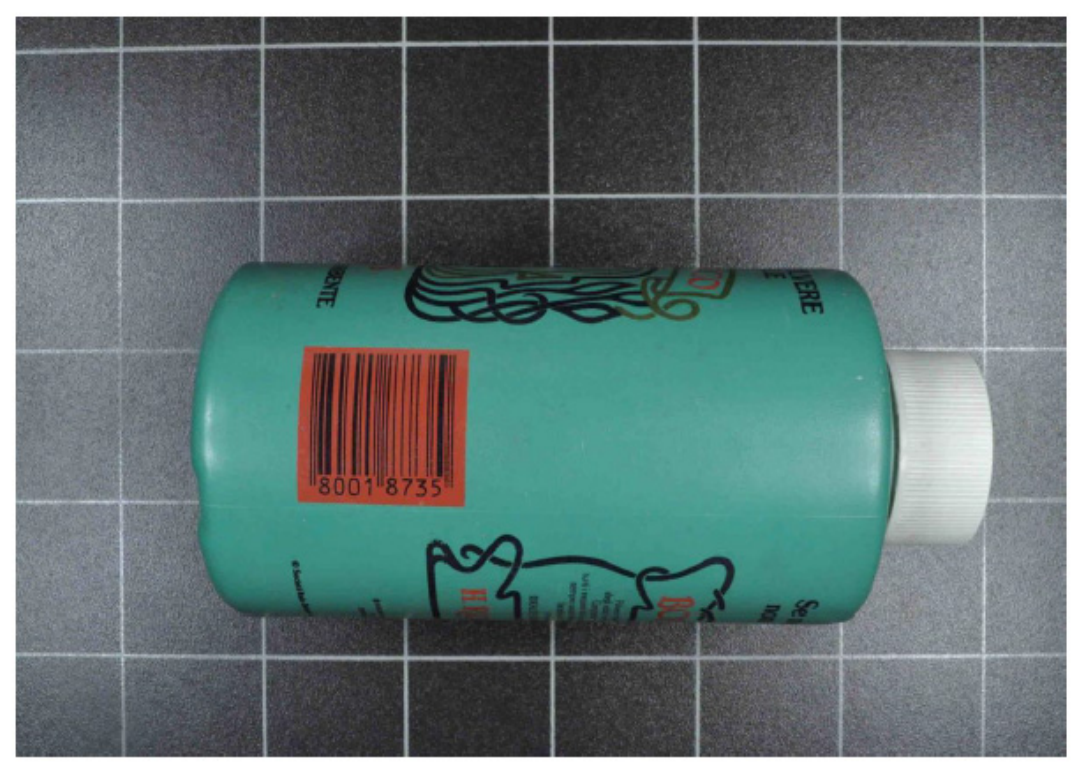

Figure A3. Side of Talc Bottle Showing Barcode

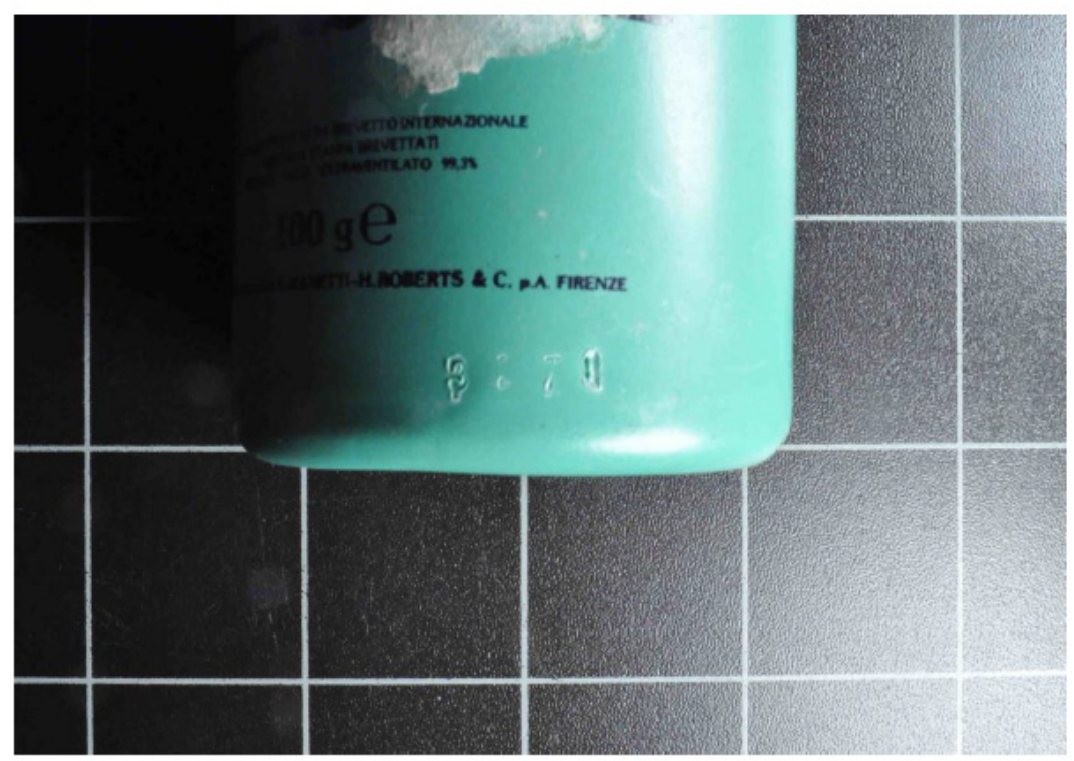

Figure A4. Bottom of Talc Bottle Showing Imprint of Date 


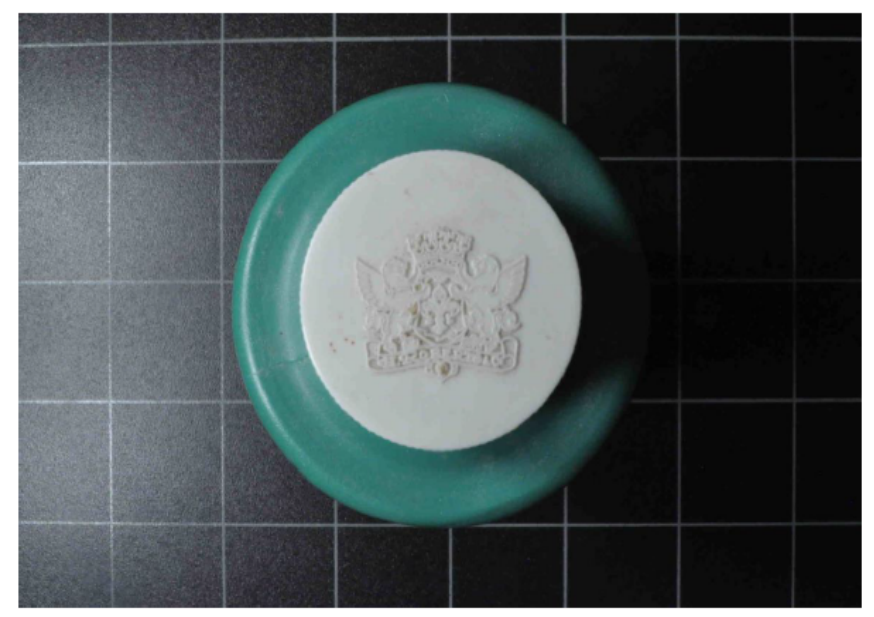

Figure A5. Top of Talc Bottle

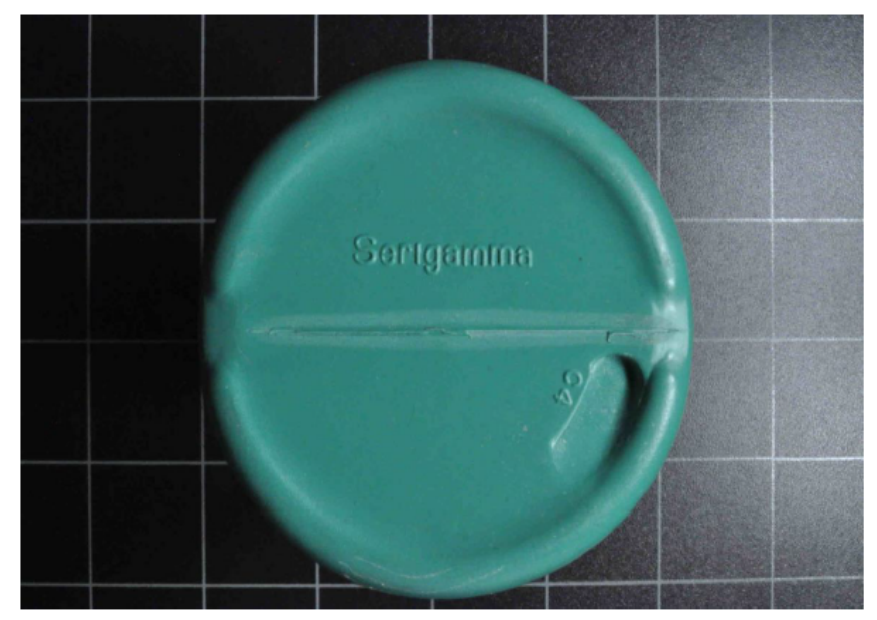

Figure A6. Base of Talc Bottle

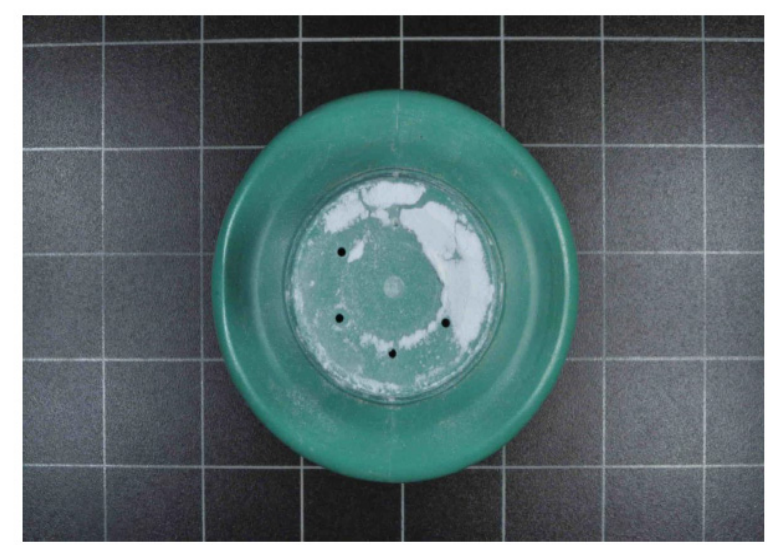

Figure A7. Top of Talc Bottle With Cap Removed 
Figures B.

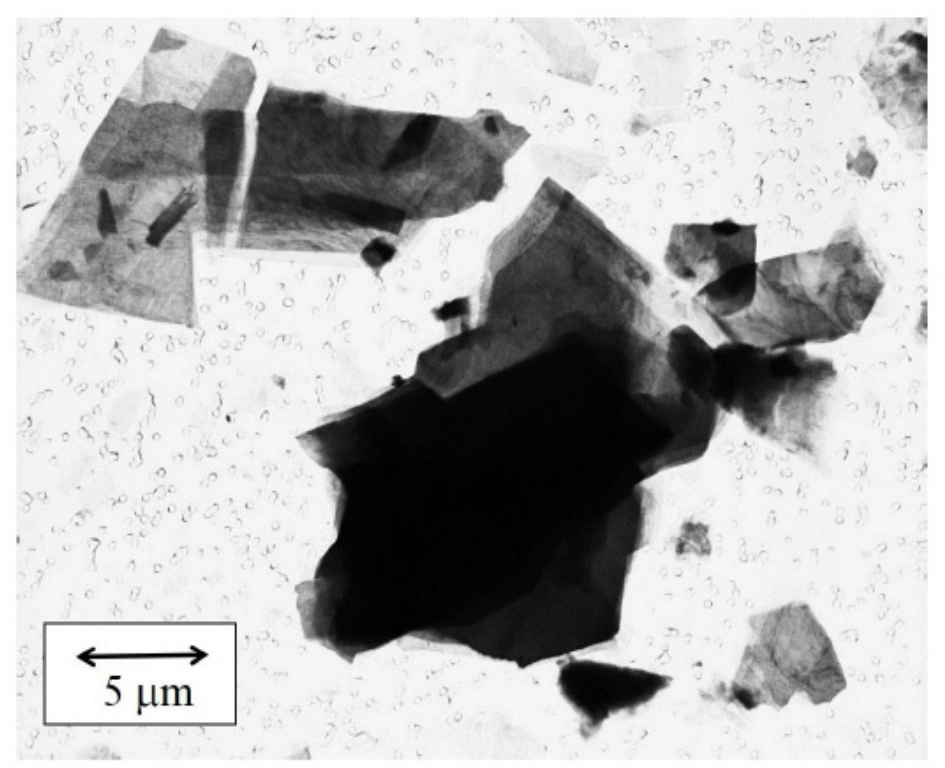

Figure B1. TEM Micrograph Showing Platy Talc Particles

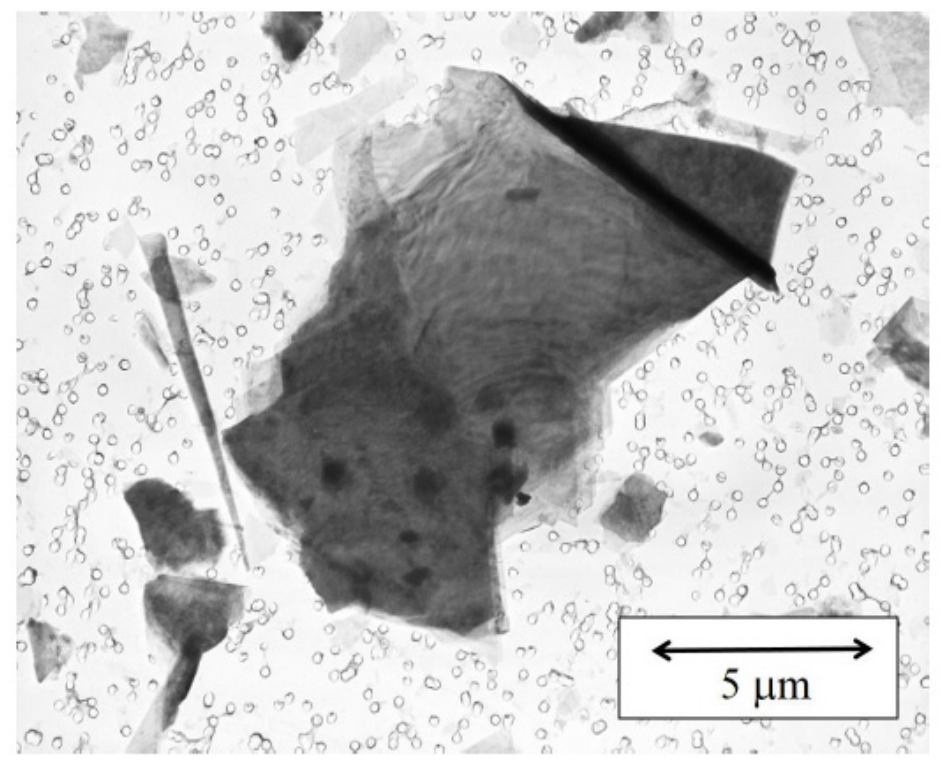

e B2. TEM Micrograph Showing Platy Talc and an Elongated Talc Fragment 


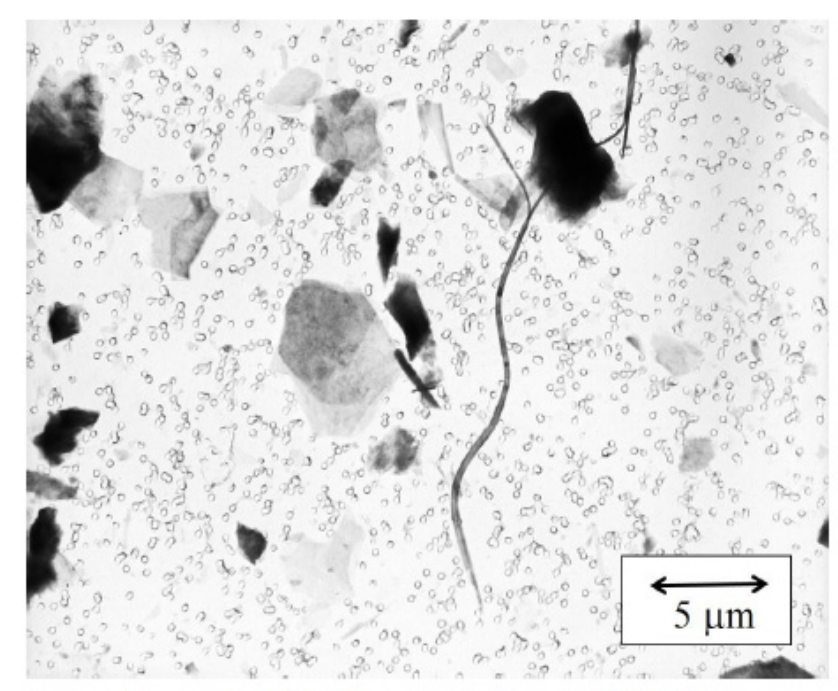

Figure B3. TEM Micrograph Showing Talc Fibre

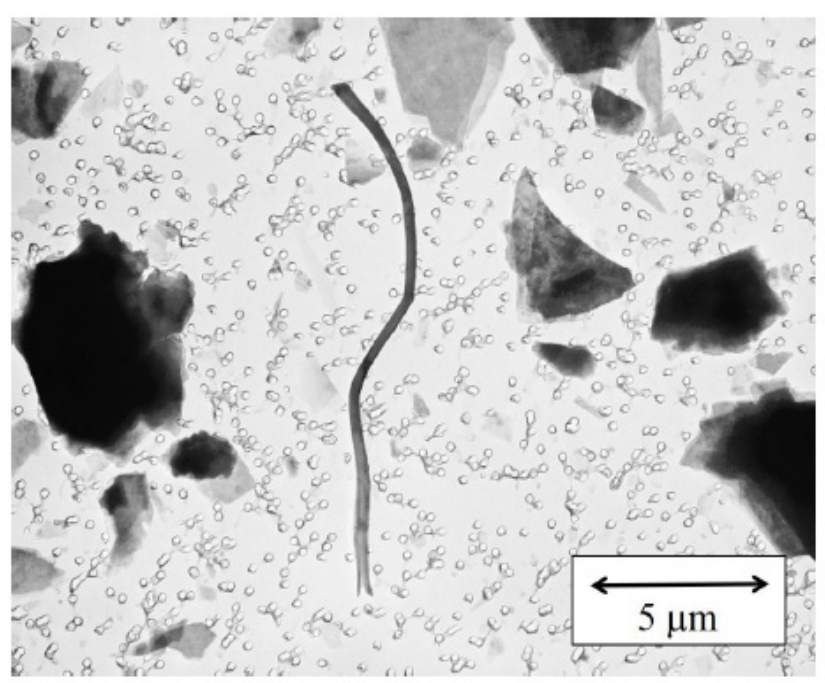

Figure B4. TEM Micrograph Showing Talc Fibre 


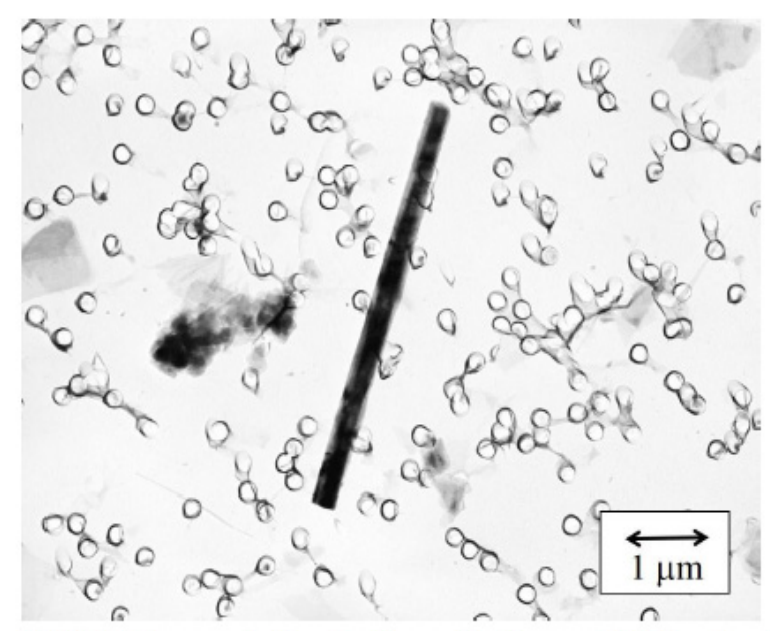

Figure B5. TEM Micrograph Showing Tremolite Fibre on Grid Opening A-G3-2

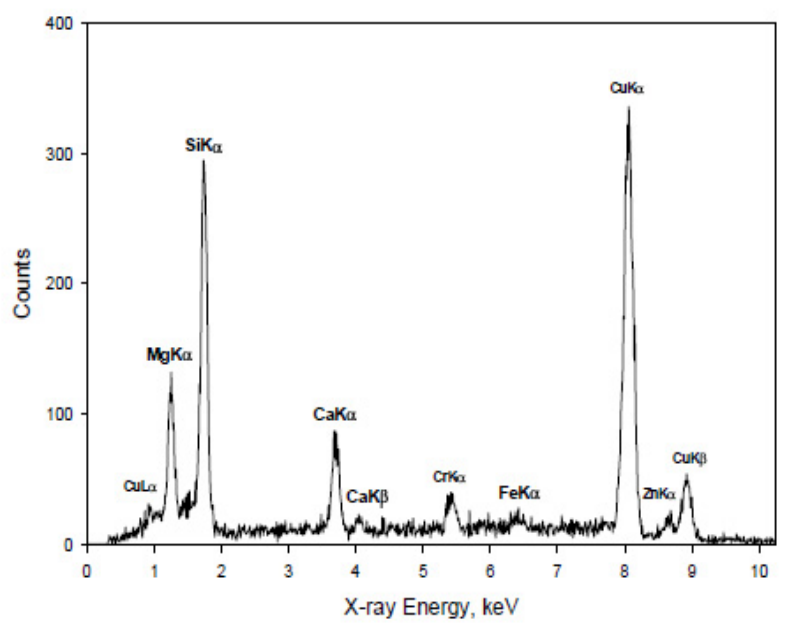

Figure B6. EDXA Spectrum Obtained from Tremolite Fibre on Grid Opening A-G3-2 


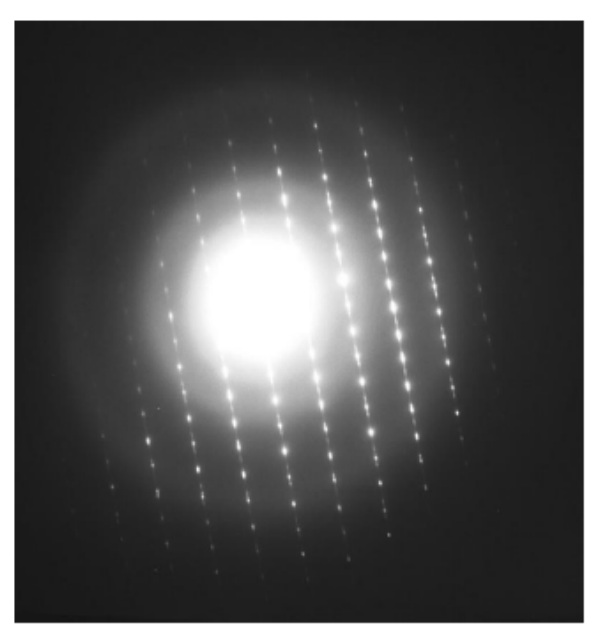

Figure B7. SAED Pattern Obtained From Tremolite Fibre on Grid Opening A-G3-2

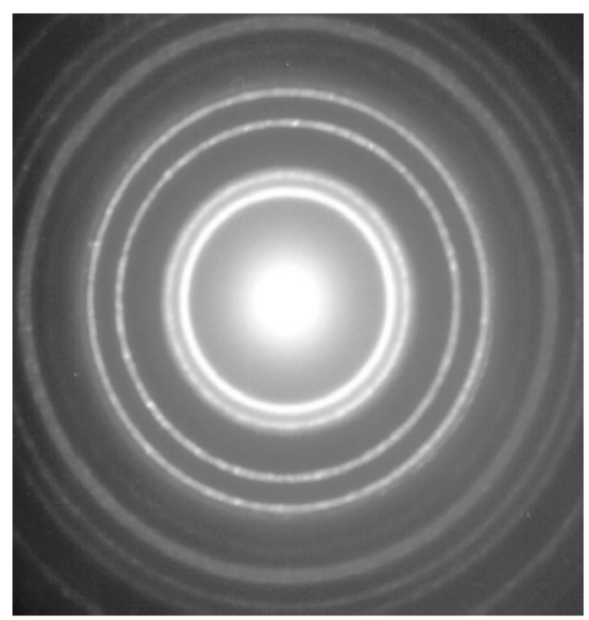

Figure B8. Calibration SAED Pattern From Thin Film Gold Standard 


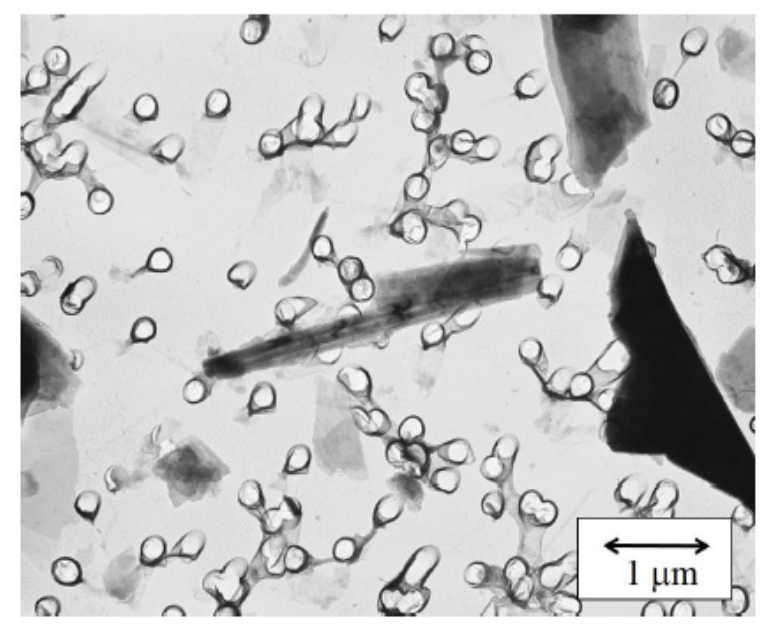

Figure B9. TEM Micrograph Showing Tremolite Fibre on Grid Opening B-C3-6

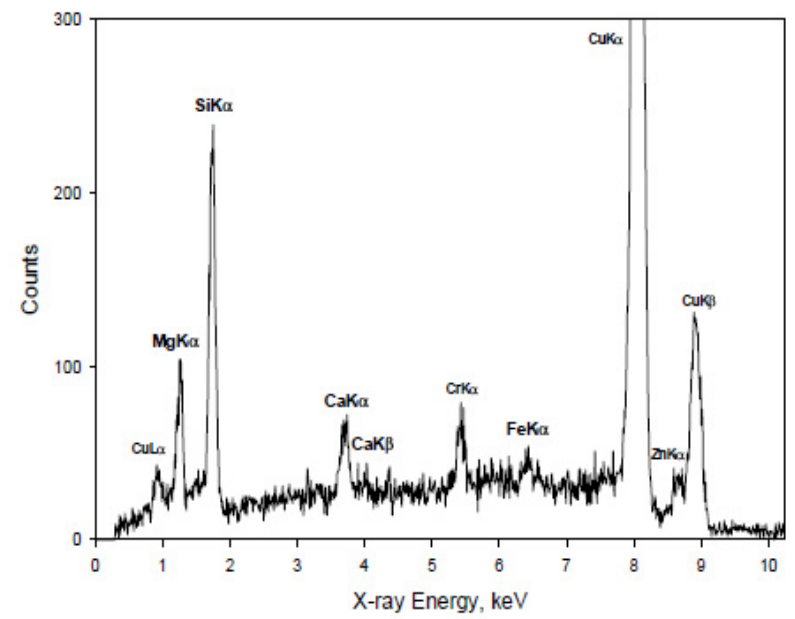

Figure B10. EDXA Spectrum Obtained From Tremolite Fibre on Grid Opening B-C3-6 


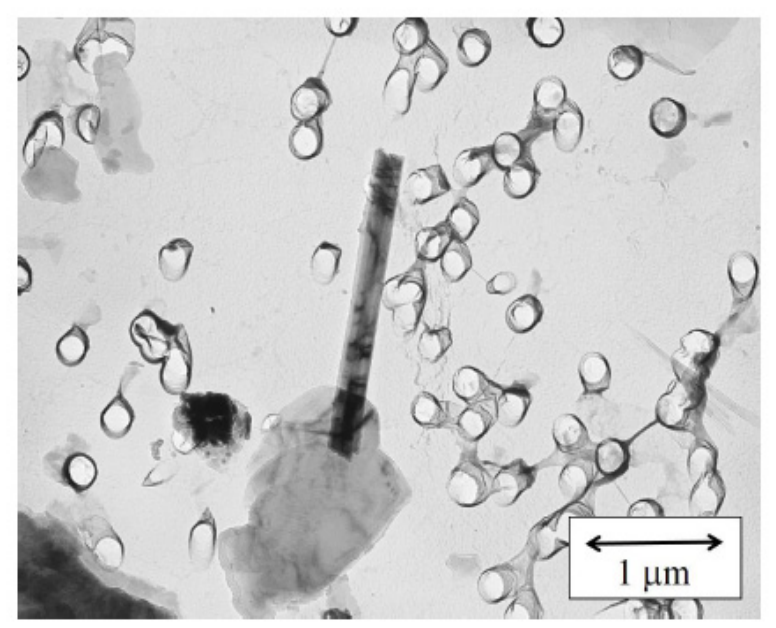

Figure B11. TEM Micrograph Showing Tremolite Fibre on Grid Opening C-C3-4

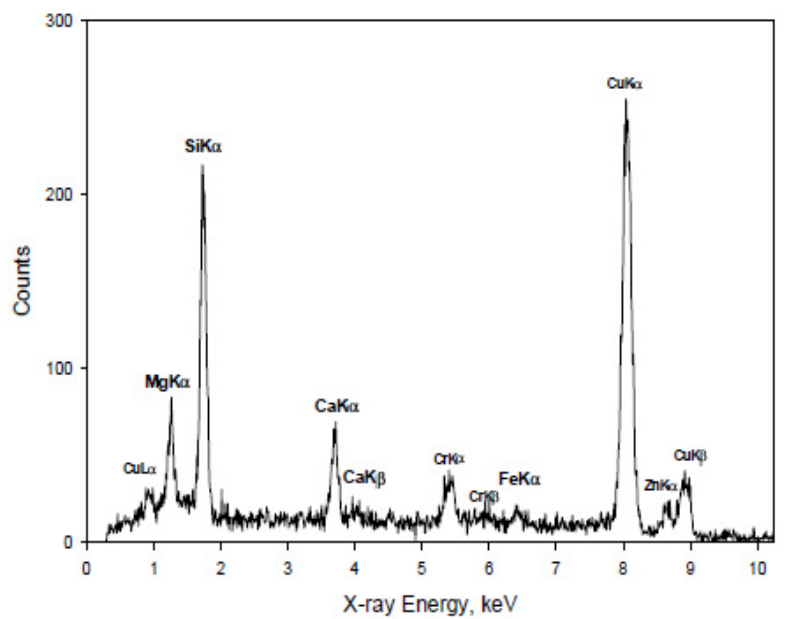

Figure B12. EDXA Spectrum Obtained from Tremolite Fibre on Grid Opening C-C3-4 
Table 2. TEM analysis

$\begin{array}{llll}\text { Sample Number: } & \text { 15C023-1-0.1 } & \text { Sub-Sample Weight }(\mathrm{g}): & 0.1045 \\ \text { Sample Description: } & \text { ROBERT'S BOROTALCO TALC } & \text { Dispersal Volume }(\mathrm{mL}): & 100 \\ & 100 \mathrm{~g} \text { Bottle Dated 3:71 } & \text { Volume Filtered }(\mathrm{mL}): & 0.10 \\ & \text { GTIN 8001 8735, Received 2015-11-23 } & \text { Filter Area }\left(\mathrm{mm}^{2}\right): & 199 \\ \text { Initials of Analyst: } & \text { EJC } & \text { Mean G.O. Area }\left(\mathrm{mm}^{2}\right): & 0.01033 \\ & & \text { Grid Openings Examined: } & 100\end{array}$

\begin{tabular}{|c|c|c|c|c|c|c|c|c|c|}
\hline $\begin{array}{c}\text { Grid } \\
\text { Opening }\end{array}$ & Grid/ID & $\begin{array}{l}\text { Structure } \\
\text { Number }\end{array}$ & Class & $\begin{array}{c}\text { Structure } \\
\text { Type }\end{array}$ & $\begin{array}{c}\text { Length } \\
(\mu \mathrm{m})\end{array}$ & $\begin{array}{l}\text { Width } \\
(\mu \mathrm{m})\end{array}$ & EDXA File & Photo File & Comments \\
\hline 1 & A-C3-4 & & NSD & & & & & & \\
\hline 2 & $A-E 3-1$ & & NSD & & & & & & \\
\hline 3 & $A-E 3-4$ & & NSD & & & & & & \\
\hline 4 & $A-F 3-1$ & & NSD & & & & & & \\
\hline 5 & $A-F 3-4$ & & NSD & & & & & & \\
\hline 6 & A-G3-1 & & NSD & & & & & & \\
\hline 7 & A-G4-1 & & NSD & & & & & & \\
\hline 8 & A-F $4-1$ & & NSD & & & & & & \\
\hline 9 & A-E4-4 & & NSD & & & & & & \\
\hline 10 & A-E4-1 & & NSD & & & & & & \\
\hline 11 & A-C4-4 & & NSD & & & & & & \\
\hline 12 & A-C4-1 & & NSD & & & & & & \\
\hline 13 & A-C5-1 & & NSD & & & & & & \\
\hline 14 & A-C5-4 & & NSD & & & & & & \\
\hline 15 & A-E5-1 & & NSD & & & & & & \\
\hline 16 & A-E5-4 & & NSD & & & & & & \\
\hline 17 & A-F5-4 & & NSD & & & & & & \\
\hline 18 & A-G5-1 & & NSD & & & & & & \\
\hline 19 & A-G5-4 & & NSD & & & & & & \\
\hline 20 & A-G4-6 & & NSD & & & & & & \\
\hline 21 & A-G4-3 & & NSD & & & & & & \\
\hline 22 & A-F $4-6$ & & NSD & & & & & & \\
\hline 23 & A-F $4-3$ & & NSD & & & & & & \\
\hline 24 & $A-E 4-6$ & & NSD & & & & & & \\
\hline 25 & $A-E 4-3$ & & NSD & & & & & & \\
\hline 26 & A-C4-6 & & NSD & & & & & & \\
\hline 27 & $\mathrm{~A}-\mathrm{C} 4-3$ & & NSD & & & & & & \\
\hline 28 & A-B4-6 & & NSD & & & & & & \\
\hline 29 & A-C5-3 & & NSD & & & & & & \\
\hline 30 & A-C5-6 & & NSD & & & & & & \\
\hline
\end{tabular}




\begin{tabular}{|c|c|c|c|c|c|c|c|c|c|}
\hline $\begin{array}{c}\text { Grid } \\
\text { Opening }\end{array}$ & Grid/ID & $\begin{array}{l}\text { Structure } \\
\text { Number }\end{array}$ & Class & $\begin{array}{l}\text { Structure } \\
\text { Type }\end{array}$ & $\begin{array}{l}\text { Length } \\
(\mu \mathrm{m})\end{array}$ & $\begin{array}{l}\text { Width } \\
(\mu \mathrm{m})\end{array}$ & EDXA File & Photo File & Comments \\
\hline 31 & A-E5-6 & & NSD & & & & & & \\
\hline 32 & $A-F 5-3$ & & NSD & & & & & & \\
\hline 33 & A-F5- 6 & & NSD & & & & & & \\
\hline 34 & A-G5-3 & & NSD & & & & & & \\
\hline 35 & B-C $3-4$ & & NSD & & & & & & \\
\hline 36 & $B-E 3-1$ & & NSD & & & & & & \\
\hline 37 & B-E3-4 & & NSD & & & & & & \\
\hline 38 & B-F3-4 & & NSD & & & & & & \\
\hline 39 & B-G3-1 & & NSD & & & & & & \\
\hline 40 & B-G4-1 & & NSD & & & & & & \\
\hline 41 & B-F $4-4$ & & NSD & & & & & & \\
\hline 42 & B-F $-1-1$ & & NSD & & & & & & \\
\hline 43 & B-E4-4 & & NSD & & & & & & \\
\hline 44 & B-E4-1 & & NSD & & & & & & \\
\hline 45 & B-C4-4 & & NSD & & & & & & \\
\hline 46 & B-C4-1 & & NSD & & & & & & \\
\hline 47 & B-C5-1 & & NSD & & & & & & \\
\hline 48 & B-C5-4 & & NSD & & & & & & \\
\hline 49 & B-E5-1 & & NSD & & & & & & \\
\hline 50 & B-E5-4 & & NSD & & & & & & \\
\hline 51 & B-F5-1 & & NSD & & & & & & \\
\hline 52 & B-F5-4 & & NSD & & & & & & \\
\hline 53 & B-G5-1 & & NSD & & & & & & \\
\hline 54 & B-G5-4 & & NSD & & & & & & \\
\hline 55 & B-G4-6 & & NSD & & & & & & \\
\hline 56 & B-G4-3 & & NSD & & & & & & \\
\hline 57 & B-F4-6 & & NSD & & & & & & \\
\hline 58 & B-F $4-3$ & & NSD & & & & & & \\
\hline 59 & $B-E 4-3$ & & NSD & & & & & & \\
\hline 60 & B-C4-6 & & NSD & & & & & & \\
\hline
\end{tabular}




\begin{tabular}{|c|c|c|c|c|c|c|c|c|c|}
\hline $\begin{array}{c}\text { Grid } \\
\text { Opening }\end{array}$ & Grid/ID & $\begin{array}{l}\text { Structure } \\
\text { Number }\end{array}$ & Class & $\begin{array}{c}\text { Structure } \\
\text { Type }\end{array}$ & $\begin{array}{l}\text { Length } \\
(\mu \mathrm{m})\end{array}$ & $\begin{array}{l}\text { Width } \\
(\mu \mathrm{m})\end{array}$ & EDXA File & Photo File & Comments \\
\hline 61 & $\mathrm{~B}-\mathrm{C} 4-3$ & & NSD & & & & & & \\
\hline 62 & B-C $3-3$ & & NSD & & & & & & \\
\hline 63 & B-C3-6 & 1 & $A D Q$ & $\mathrm{~F}$ & 3.4 & 0.23 & C023-1a & 3211 & \\
\hline 64 & B-E3-3 & & NSD & & & & & & \\
\hline 65 & $B-E 3-6$ & & NSD & & & & & & \\
\hline 66 & B-F3-3 & & NSD & & & & & & \\
\hline 67 & B-F3-6 & & NSD & & & & & & \\
\hline 68 & C-C3-1 & & NSD & & & & & & \\
\hline 69 & C-C3-4 & 2 & $A D Q$ & $\mathrm{~F}$ & 2.1 & 0.19 & C023-2a & 3213 & \\
\hline 70 & C-E3-1 & & NSD & & & & & & \\
\hline 71 & C-F3-1 & & NSD & & & & & & \\
\hline 72 & $\mathrm{C}-\mathrm{F} 3-4$ & & NSD & & & & & & \\
\hline 73 & C-G3-1 & & NSD & & & & & & \\
\hline 74 & C-G4-1 & & NSD & & & & & & \\
\hline 75 & C-F4-4 & & NSD & & & & & & \\
\hline 76 & C-F4-1 & & NSD & & & & & & \\
\hline 77 & C-E4-4 & & NSD & & & & & & \\
\hline 78 & C-E4-1 & & NSD & & & & & & \\
\hline 79 & C-C $4-4$ & & NSD & & & & & & \\
\hline 80 & C-C4-3 & & NSD & & & & & & \\
\hline 81 & $C-C 4-6$ & & NSD & & & & & & \\
\hline 82 & C-E4-3 & & NSD & & & & & & \\
\hline 83 & $C-E 4-6$ & & NSD & & & & & & \\
\hline 84 & $\mathrm{C}-\mathrm{F} 4-3$ & & NSD & & & & & & \\
\hline 85 & C-G4-3 & & NSD & & & & & & \\
\hline 86 & C-F5-4 & & NSD & & & & & & \\
\hline 87 & C-F5-1 & & NSD & & & & & & \\
\hline 88 & C-E5-4 & & NSD & & & & & & \\
\hline 89 & C-E5-1 & & NSD & & & & & & \\
\hline 90 & C-C5-4 & & NSD & & & & & & \\
\hline
\end{tabular}

\begin{tabular}{|c|c|c|c|c|c|c|c|c|c|}
\hline $\begin{array}{c}\text { Grid } \\
\text { Opening }\end{array}$ & Grid/ID & $\begin{array}{c}\text { Structure } \\
\text { Number }\end{array}$ & Class & $\begin{array}{c}\text { Structure } \\
\text { Type }\end{array}$ & $\begin{array}{c}\text { Length } \\
(\mu \mathrm{m})\end{array}$ & $\begin{array}{c}\text { Width } \\
(\mu \mathrm{m})\end{array}$ & EDXA File & Photo File & Comments \\
\hline 91 & C-C5-3 & & NSD & & & & & & \\
\hline 92 & C-C5-6 & & NSD & & & & & & \\
\hline 93 & C-E5-3 & & NSD & & & & & & \\
\hline 94 & C-E5-6 & & NSD & & & & & & \\
\hline 95 & C-F5-3 & & NSD & & & & & & \\
\hline 96 & C-F5-6 & & NSD & & & & & & \\
\hline 97 & C-G5-3 & & NSD & & & & & & \\
\hline 98 & C-G3-3 & & NSD & & & & & & \\
\hline 99 & C-F3-3 & & NSD & & & & & & \\
\hline 100 & C-E3-6 & & NSD & & & & & & \\
\hline
\end{tabular}




\begin{tabular}{llll} 
Sample Number: & 15C023-FB & Sub-Sample Weight $(\mathrm{g}):$ & 0.1045 \\
Sample Description: & ROBERT'S BOROTALCO TALC & Dispersal Volume $(\mathrm{mL}):$ & 100 \\
& Laboratory Funnel Blank & Volume Filtered $(\mathrm{mL}):$ & 40 \\
& \multirow{2}{*}{ EJC } & Filter Area $\left(\mathrm{mm}^{2}\right):$ & 199 \\
Initials of Analyst: & Mean G.O. Area $\left(\mathrm{mm}^{2}\right):$ & 0.01046 \\
& & Grid Openings Examined: & 100
\end{tabular}

\begin{tabular}{|c|c|c|c|c|c|c|c|c|c|}
\hline $\begin{array}{c}\text { Grid } \\
\text { Opening }\end{array}$ & Grid/ID & $\begin{array}{l}\text { Structure } \\
\text { Number }\end{array}$ & Class & $\begin{array}{c}\text { Structure } \\
\text { Type }\end{array}$ & $\begin{array}{c}\text { Length } \\
(\mu \mathrm{m})\end{array}$ & $\begin{array}{c}\text { Width } \\
(\mu \mathrm{m})\end{array}$ & EDXA File & Photo File & Comments \\
\hline 1 & A-C3-1 & & NSD & & & & & & \\
\hline 2 & A-C $3-4$ & & NSD & & & & & & \\
\hline 3 & $A-E 3-1$ & & NSD & & & & & & \\
\hline 4 & $A-E 3-4$ & & NSD & & & & & & \\
\hline 5 & A-F3-1 & & NSD & & & & & & \\
\hline 6 & A-F $3-4$ & & NSD & & & & & & \\
\hline 7 & A-G3-1 & & NSD & & & & & & \\
\hline 8 & A-G3-3 & & NSD & & & & & & \\
\hline 9 & A-F3-6 & & NSD & & & & & & \\
\hline 10 & A-F3-3 & & NSD & & & & & & \\
\hline 11 & A-E3-6 & & NSD & & & & & & \\
\hline 12 & A-E3-3 & & NSD & & & & & & \\
\hline 13 & A-C3-6 & & NSD & & & & & & \\
\hline 14 & A-C $3-3$ & & NSD & & & & & & \\
\hline 15 & A-C4-1 & & NSD & & & & & & \\
\hline 16 & A-C $4-4$ & & NSD & & & & & & \\
\hline 17 & A-E4-1 & & NSD & & & & & & \\
\hline 18 & A-E4-4 & & NSD & & & & & & \\
\hline 19 & A-F $4-1$ & & NSD & & & & & & \\
\hline 20 & A-F $4-4$ & & NSD & & & & & & \\
\hline 21 & A-G4-1 & & NSD & & & & & & \\
\hline 22 & A-G4-3 & & NSD & & & & & & \\
\hline 23 & A-F $4-6$ & & NSD & & & & & & \\
\hline 24 & A-F4-3 & & NSD & & & & & & \\
\hline 25 & A-E4-6 & & NSD & & & & & & \\
\hline 26 & A-E4-3 & & NSD & & & & & & \\
\hline 27 & A-C4-6 & & NSD & & & & & & \\
\hline 28 & A-C4-3 & & NSD & & & & & & \\
\hline 29 & A-C5-1 & & NSD & & & & & & \\
\hline 30 & A-C $5-4$ & & NSD & & & & & & \\
\hline
\end{tabular}




\begin{tabular}{|c|c|c|c|c|c|c|c|c|c|}
\hline $\begin{array}{c}\text { Grid } \\
\text { Opening }\end{array}$ & Grid/ID & $\begin{array}{l}\text { Structure } \\
\text { Number }\end{array}$ & Class & $\begin{array}{c}\text { Structure } \\
\text { Type }\end{array}$ & $\begin{array}{l}\text { Length } \\
(\mu \mathrm{m})\end{array}$ & $\begin{array}{c}\text { Width } \\
(\mu \mathrm{m})\end{array}$ & EDXA File & Photo File & Comments \\
\hline 31 & A-E5-1 & & NSD & & & & & & \\
\hline 32 & $A-E 5-4$ & & NSD & & & & & & \\
\hline 33 & A-F5-1 & & NSD & & & & & & \\
\hline 34 & A-F5-4 & & NSD & & & & & & \\
\hline 35 & B-C3-1 & & NSD & & & & & & \\
\hline 36 & B-C3-4 & & NSD & & & & & & \\
\hline 37 & B-E3-1 & & NSD & & & & & & \\
\hline 38 & B-E3-4 & & NSD & & & & & & \\
\hline 39 & B-F3-1 & & NSD & & & & & & \\
\hline 40 & B-F3-4 & & NSD & & & & & & \\
\hline 41 & B-G3-1 & & NSD & & & & & & \\
\hline 42 & B-G3-3 & & NSD & & & & & & \\
\hline 43 & B-G4-1 & & NSD & & & & & & \\
\hline 44 & B-F4-4 & & NSD & & & & & & \\
\hline 45 & B-F4-1 & & NSD & & & & & & \\
\hline 46 & B-E4-4 & & NSD & & & & & & \\
\hline 47 & B-E4-1 & & NSD & & & & & & \\
\hline 48 & B-C4-4 & & NSD & & & & & & \\
\hline 49 & B-C4-1 & & NSD & & & & & & \\
\hline 50 & B-C4-3 & & NSD & & & & & & \\
\hline 51 & B-C4-6 & & NSD & & & & & & \\
\hline 52 & B-E4-3 & & NSD & & & & & & \\
\hline 53 & B-E4-6 & & NSD & & & & & & \\
\hline 54 & B-F4-3 & & NSD & & & & & & \\
\hline 55 & B-F $4-6$ & & NSD & & & & & & \\
\hline 56 & B-G4-3 & & NSD & & & & & & \\
\hline 57 & B-G5-1 & & NSD & & & & & & \\
\hline 58 & B-F5-4 & & NSD & & & & & & \\
\hline 59 & B-F5-1 & & NSD & & & & & & \\
\hline 60 & B-E5-4 & & NSD & & & & & & \\
\hline
\end{tabular}




\begin{tabular}{|c|c|c|c|c|c|c|c|c|c|}
\hline $\begin{array}{c}\text { Grid } \\
\text { Opening }\end{array}$ & Grid/ID & $\begin{array}{l}\text { Structure } \\
\text { Number }\end{array}$ & Class & $\begin{array}{c}\text { Structure } \\
\text { Type }\end{array}$ & $\begin{array}{l}\text { Length } \\
(\mu \mathrm{m})\end{array}$ & $\begin{array}{l}\text { Width } \\
(\mu \mathrm{m})\end{array}$ & EDXA File & Photo File & Comments \\
\hline 61 & B-E5-1 & & NSD & & & & & & \\
\hline 62 & B-C5-4 & & NSD & & & & & & \\
\hline 63 & B-C5-1 & & NSD & & & & & & \\
\hline 64 & B-C5-3 & & NSD & & & & & & \\
\hline 65 & B-C5-6 & & NSD & & & & & & \\
\hline 68 & B-E5-3 & & NSD & & & & & & \\
\hline 67 & B-E5-6 & & NSD & & & & & & \\
\hline 68 & C-C3-4 & & NSD & & & & & & \\
\hline 69 & C-E3-1 & & NSD & & & & & & \\
\hline 70 & C-E3-4 & & NSD & & & & & & \\
\hline 71 & C-F3-1 & & NSD & & & & & & \\
\hline 72 & C-F3-4 & & NSD & & & & & & \\
\hline 73 & C-G3-1 & & NSD & & & & & & \\
\hline 74 & C-G3-3 & & NSD & & & & & & \\
\hline 75 & C-F3-6 & & NSD & & & & & & \\
\hline 76 & C-F3-3 & & NSD & & & & & & \\
\hline 77 & C-E3-6 & & NSD & & & & & & \\
\hline 78 & C-E3-3 & & NSD & & & & & & \\
\hline 79 & C-C3-6 & & NSD & & & & & & \\
\hline 80 & C-C4-1 & & NSD & & & & & & \\
\hline 81 & C-C4-4 & & NSD & & & & & & \\
\hline 82 & C-E4-1 & & NSD & & & & & & \\
\hline 83 & C-E4-4 & & NSD & & & & & & \\
\hline 84 & $\mathrm{C}-\mathrm{F} 4-1$ & & NSD & & & & & & \\
\hline 85 & C-F4-4 & & NSD & & & & & & \\
\hline 86 & C-G4-1 & & NSD & & & & & & \\
\hline 87 & C-G4-3 & & NSD & & & & & & \\
\hline 88 & C-F4-6 & & NSD & & & & & & \\
\hline 89 & $\mathrm{C}-\mathrm{F} 4-3$ & & NSD & & & & & & \\
\hline 90 & C-E4-6 & & NSD & & & & & & \\
\hline
\end{tabular}

\begin{tabular}{|c|c|c|c|c|c|c|c|c|c|}
\hline $\begin{array}{c}\text { Grid } \\
\text { Opening }\end{array}$ & Grid//D & $\begin{array}{c}\text { Structure } \\
\text { Number }\end{array}$ & Class & $\begin{array}{c}\text { Structure } \\
\text { Type }\end{array}$ & $\begin{array}{c}\text { Length } \\
(\mu \mathrm{m})\end{array}$ & $\begin{array}{c}\text { Width } \\
(\mu \mathrm{m})\end{array}$ & EDXA File & Photo File & Comments \\
\hline 91 & C-E4-3 & & NSD & & & & & & \\
\hline 92 & C-C4-6 & & NSD & & & & & & \\
\hline 93 & C-C4-3 & & NSD & & & & & & \\
\hline 94 & C-C5-1 & & NSD & & & & & & \\
\hline 95 & C-C5-4 & & NSD & & & & & & \\
\hline 96 & C-E5-1 & & NSD & & & & & & \\
\hline 97 & C-E5-4 & & NSD & & & & & & \\
\hline 98 & C-F5-1 & & NSD & & & & & & \\
\hline 98 & C-F5-4 & & NSD & & & & & & \\
\hline 100 & C-G5-1 & & NSD & & & & & & \\
\hline
\end{tabular}




\section{Conflicts of interest}

Professor Ilgren has acted as consultant to both the talc and asbestos industries.

Sr. Sartorio has never worked for the talc or asbestos industries. Indirect associations are described in the text.

Dr Hoskins has acted as consultant for the chrysotile industry.

\section{Copyrights}

Copyright for this article is retained by the author(s), with first publication rights granted to the journal.

This is an open-access article distributed under the terms and conditions of the Creative Commons Attribution license (http://creativecommons.org/licenses/by/4.0/). 